\title{
Molecular Basis of Epstein-Barr Virus Latency Establishment and Lytic Reactivation
}

\author{
Takayuki Murata $1,2, *\left(\mathbb{D}\right.$, Atsuko Sugimoto ${ }^{1,3}$, Tomoki Inagaki ${ }^{2,4}$, Yusuke Yanagi ${ }^{2}$, Takahiro Watanabe ${ }^{2}$, \\ Yoshitaka Sato $^{2}$ (D) and Hiroshi Kimura ${ }^{2}$ (D) \\ 1 Department of Virology and Parasitology, Fujita Health University School of Medicine, \\ Toyoake 470-1192, Japan; asugi@fujita-hu.ac.jp \\ 2 Department of Virology, Nagoya University Graduate School of Medicine, Nagoya 466-8550, Japan; \\ tinagaki@ucdavis.edu (T.I.); yusuke.yanagi@med.nagoya-u.ac.jp (Y.Y.); \\ t.nabe.watanabe@med.nagoya-u.ac.jp (T.W.); yssato@med.nagoya-u.ac.jp (Y.S.); \\ hkimura@med.nagoya-u.ac.jp (H.K.) \\ 3 Clinical Research Center, National Hospital Organization Nagoya Medical Center, Nagoya 460-0001, Japan \\ 4 Department of Dermatology, School of Medicine, University of California Davis (UC Davis), \\ Sacramento, CA 95817, USA \\ * Correspondence: tmurata@fujita-hu.ac.jp
}

check for updates

Citation: Murata, T.; Sugimoto, A.; Inagaki, T.; Yanagi, Y.; Watanabe, T.; Sato, Y.; Kimura, H. Molecular Basis of Epstein-Barr Virus Latency Establishment and Lytic Reactivation. Viruses 2021, 13, 2344. https:// doi.org/10.3390/v13122344

Academic Editor: Ke Lan

Received: 28 October 2021

Accepted: 22 November 2021

Published: 23 November 2021

Publisher's Note: MDPI stays neutral with regard to jurisdictional claims in published maps and institutional affiliations.

Copyright: (c) 2021 by the authors. Licensee MDPI, Basel, Switzerland. This article is an open access article distributed under the terms and conditions of the Creative Commons Attribution (CC BY) license (https:// creativecommons.org/licenses/by/ $4.0 /)$.

\begin{abstract}
Epstein-Barr virus (EBV) is a causative agent of infectious mononucleosis and several types of cancer. Like other herpesviruses, it establishes an asymptomatic, life-long latent infection, with occasional reactivation and shedding of progeny viruses. During latency, EBV expresses a small number of viral genes, and exists as an episome in the host-cell nucleus. Expression patterns of latency genes are dependent on the cell type, time after infection, and milieu of the cell (e.g., germinal center or peripheral blood). Upon lytic induction, expression of the viral immediate-early genes, BZLF1 and BRLF1, are induced, followed by early gene expression, viral DNA replication, late gene expression, and maturation and egress of progeny virions. Furthermore, EBV reactivation involves more than just progeny production. The EBV life cycle is regulated by signal transduction, transcription factors, promoter sequences, epigenetics, and the 3D structure of the genome. In this article, the molecular basis of EBV latency establishment and reactivation is summarized.
\end{abstract}

Keywords: EBV; latency; reactivation; transcription; epigenetics; oncogenesis

\section{Introduction}

Epstein-Barr virus (EBV) is an enveloped virus with virions 100-200 nm in diameter [1]. A linear, double-stranded viral DNA genome is contained in the icosahedral nucleocapsid, and the component between the envelope and nucleocapsid is termed the tegument. The EBV genome is about $175 \mathrm{~kb}$ and encodes about 80 open reading frames and 44 non-coding RNAs. It is a member of the $\gamma$-herpesvirus subfamily, together with Kaposi sarcoma-associated herpesvirus (KSHV).

EBV was discovered in 1964 in an endemic Burkitt lymphoma (BL) cell culture [1]. As the fourth herpesvirus to be identified, it was named human herpesvirus 4 (HHV-4). Although discovered in an African tumor specimen, it was soon clear that EBV is ubiquitous, irrespective of race, nationality, sex, hygienic status, occupation, and presence of tumor. Indeed, more than $95 \%$ of adults worldwide are asymptomatically infected with EBV. The spread of EBV is mediated by saliva. Many people are infected with the virus during childhood, i.e., as babies or toddlers, mostly via family members. Others are infected in their teens or later, usually through friends or partners. Infection during infancy is not associated with obvious symptoms, whereas infection during/after the teenage years frequently causes infectious mononucleosis (IM) [2]. After initial infection, the virus establishes latency predominantly in B cells and cannot be eradicated. From time to time, latent EBV is reactivated, executes its lytic cycle, and produces progeny viruses, which are 
excreted in saliva [3,4]. Less frequently, persistent EBV infection results in the development of several types of cancers in lymphocytes and epithelial cells. Such EBV-associated cancers include BL, Hodgkin's lymphoma (HL), post-transplant lymphoproliferative disorder (PTLD), NK/T cell lymphoma (NKTCL), chronic active EBV infection (CAEBV), diffuse large B cell lymphoma (DLBCL), nasopharyngeal carcinoma (NPC), and gastric carcinoma (GC) [5].

Herpesviruses establish latency, although the site of latency depends on the virus (Table 1) [6]. For example, herpes simplex virus 1 (HSV-1) lurks in neurons and human cytomegalovirus (HCMV) in precursor cells of myeloid lineages. Two human $\gamma$-herpesviruses, EBV and KSHV, maintain latency predominantly in B cells in vivo. It must also be mentioned that latent infection of EBV is more complex and variable than those of other herpesviruses. The latent form of EBV infection is further categorized into five patterns, Latency 0 to III (Table 2), depending on the viral latent gene expression [7]. The molecular basis of switching to the lytic cycle (i.e., lytic switch genes, transcriptional activators, repressors, and signalings) also differs among herpesviruses, likely because the site of latency is different (Table 1). In this review article, the molecular mechanisms of EBV latency and reactivation are explained.

Table 1. Latency and lytic reactivation of human herpesviruses.

\begin{tabular}{|c|c|c|c|c|c|c|c|}
\hline & $\begin{array}{l}\text { Sub- } \\
\text { Family }\end{array}$ & Site of Latency & $\begin{array}{l}\text { Viral Gene } \\
\text { Expressed in } \\
\text { Latency }\end{array}$ & $\begin{array}{c}\text { Trigger of } \\
\text { Reactivation }\end{array}$ & $\begin{array}{l}\text { Viral Lytic } \\
\text { Swithch } \\
\text { Gene }\end{array}$ & $\begin{array}{c}\text { Transcriptional } \\
\text { Activator of } \\
\text { Reactivation }\end{array}$ & $\begin{array}{l}\text { Transcriptional } \\
\text { Repressor of } \\
\text { Reactivation }\end{array}$ \\
\hline HSV-1 & \multirow{2}{*}{$\mathrm{a}$} & $\begin{array}{l}\text { neuron cells in } \\
\text { trigeminal } \\
\text { ganglia }\end{array}$ & LATs & $\begin{array}{l}\text { stressors, } \\
\text { immune } \\
\text { suppression }\end{array}$ & ICP0, ICP4 & $\begin{array}{c}\text { HCF1, SP1, GR, KLF15, } \\
\text { ROS }\end{array}$ & NGF \\
\hline VZV & & $\begin{array}{c}\text { neuron cells in } \\
\text { dorsal root } \\
\text { ganglia }\end{array}$ & ORF63, VLT & $\begin{array}{l}\text { stressors, } \\
\text { immune } \\
\text { suppression }\end{array}$ & IE62 & $\begin{array}{l}\text { HCF1, SP1, YY1, } \\
\text { PI3K/AKT, JNK }\end{array}$ & \\
\hline HCMV & $\mathrm{b}$ & $\begin{array}{c}\text { myeloid lineages, } \\
\text { hematopoietic } \\
\text { progenitor cells, } \\
\text { monocytes }\end{array}$ & $\begin{array}{l}\text { UL138, UL81- } \\
\text { 82ast(LUNA), } \\
\text { US28, UL144, } \\
\text { UL111A(vIL10) }\end{array}$ & $\begin{array}{l}\text { stressors, } \\
\text { immune } \\
\text { suppression, } \\
\text { differentiation, } \\
\text { growth factor }\end{array}$ & $\begin{array}{l}\text { IE86(UL122), } \\
\text { IE72(UL123) }\end{array}$ & $\begin{array}{l}\text { PU.1, SP1, C/EBP, } \\
\text { ATF/CREB, AP-1, } \\
\text { NFkB, PPARg, } \\
\text { RAR/RXR }\end{array}$ & $\begin{array}{c}\text { CUX1/CDP, GFI-1, } \\
\text { YY1, CTCF }\end{array}$ \\
\hline EBV & \multirow[t]{2}{*}{ g } & $\begin{array}{l}\text { B cells, epithelial } \\
\text { cells }\end{array}$ & $\begin{array}{l}\text { EBNAs, LMPs, } \\
\text { EBERs }\end{array}$ & $\begin{array}{l}\text { stressors, } \\
\text { immune } \\
\text { suppression, } \\
\text { differentiation, } \\
\text { groth factor, } \\
\text { hypoxia }\end{array}$ & $\begin{array}{l}\text { BZLF1(Zta), } \\
\text { BRLF1(Rta) }\end{array}$ & $\begin{array}{c}\text { SP1, KLF4, MEF2, } \\
\text { C/EBP, ATF/CREB, } \\
\text { AP-1, XBP1s, SMAD, } \\
\text { HIF, ROS, P53, } \\
\text { PI3K/AKT, TORC2, } \\
\text { YAP/TAZ, TET2, ATM, } \\
\text { BLIMP1, TAF-I/NAP1, } \\
\text { NFATc1, CASP1 }\end{array}$ & $\begin{array}{l}\text { ZEB, NFkB, MYC, } \\
\text { YY1, JDP2, NO, } \\
\text { E2-2, JAK/STAT, } \\
\text { SMUBP, OCT2, } \\
\text { PAX5, BCL6, } \\
\text { ARKL1, PARP1, } \\
\text { CAF1/HIRA, } \\
\text { KAP1 }\end{array}$ \\
\hline KSHV & & $\begin{array}{l}\text { B cells, } \\
\text { endothelial cells }\end{array}$ & $\begin{array}{c}\text { LANA, vCYC, } \\
\text { vFLIP, Kaposins }\end{array}$ & $\begin{array}{c}\text { stressors, } \\
\text { immune } \\
\text { suppression, } \\
\text { differentiation, } \\
\text { groth factor, } \\
\text { hypoxia }\end{array}$ & $\begin{array}{l}\text { K-Rta } \\
\text { (ORF50) }\end{array}$ & $\begin{array}{c}\text { C/EBP, AP-1, EGR1, } \\
\text { XBP1, NFAT, HIF, ROS }\end{array}$ & $\begin{array}{c}\text { NFkB, MYC, KAP1, } \\
\text { PI3K/AKT, IFNs, } \\
\text { IRFs, HES1, } \\
\text { FOXO1 }\end{array}$ \\
\hline
\end{tabular}

Table 2. EBV latency patterns.

\begin{tabular}{ccccc}
\hline Patterns & EBERs & EBNA1 & LMP1/2 & EBNA2/3/LP \\
\hline Latency III & + & + & + & + \\
Latency IIa & + & + & + & + \\
Latency IIb & + & + & & \\
Latency I & + & + & & \\
Latency 0 & + & & & \\
\hline
\end{tabular}




\section{Establishment of Latency}

Because EBV infection of differentiated epithelial cells results in the lytic cycle [8,9], it is speculated that differentiated epithelial cells (likely stratified squamous epithelium in oral cavity or pharynx) are the initial site for EBV infection and multiplication in vivo. On the other hand, EBV infection of B cells in vitro predominantly causes latent infection, suggesting that $\mathrm{B}$ cells are the site for EBV latency. In addition, EBV chooses latent infection in many other cell types, such as established epithelial or T/NK cell lines [10,11]. Such latency-prone infection is a distinctive feature of EBV (and also KSHV); other herpesviruses (e.g., HSV) generally execute the lytic program upon de novo infection of many types of cells (Figure 1). This may be related to the fact that $\gamma$-herpesviruses have oncogenic potential. HSV must replicate as early as possible before being cleared by host immunity, because lytic replication cycle produces large quantities of viral antigens. By contrast, latent infection of EBV promotes the growth of infected B cells. Viral genomes are amplified in S phase, when cell proliferation is induced. Therefore, $\gamma$-herpesviruses use a survival strategy of slow replication in synchronization with host-cell genome replication. Mechanistically, such latency-prone infection of EBV upon de novo infection can be explained by a viral unique transactivator BZLF1 and epigenetics [12]. EBV genome DNA, released from a nucleocapsid, lacks CpG methylation and therefore BZLF1 cannot immediately bind and activate viral lytic promoters, as further detailed later.
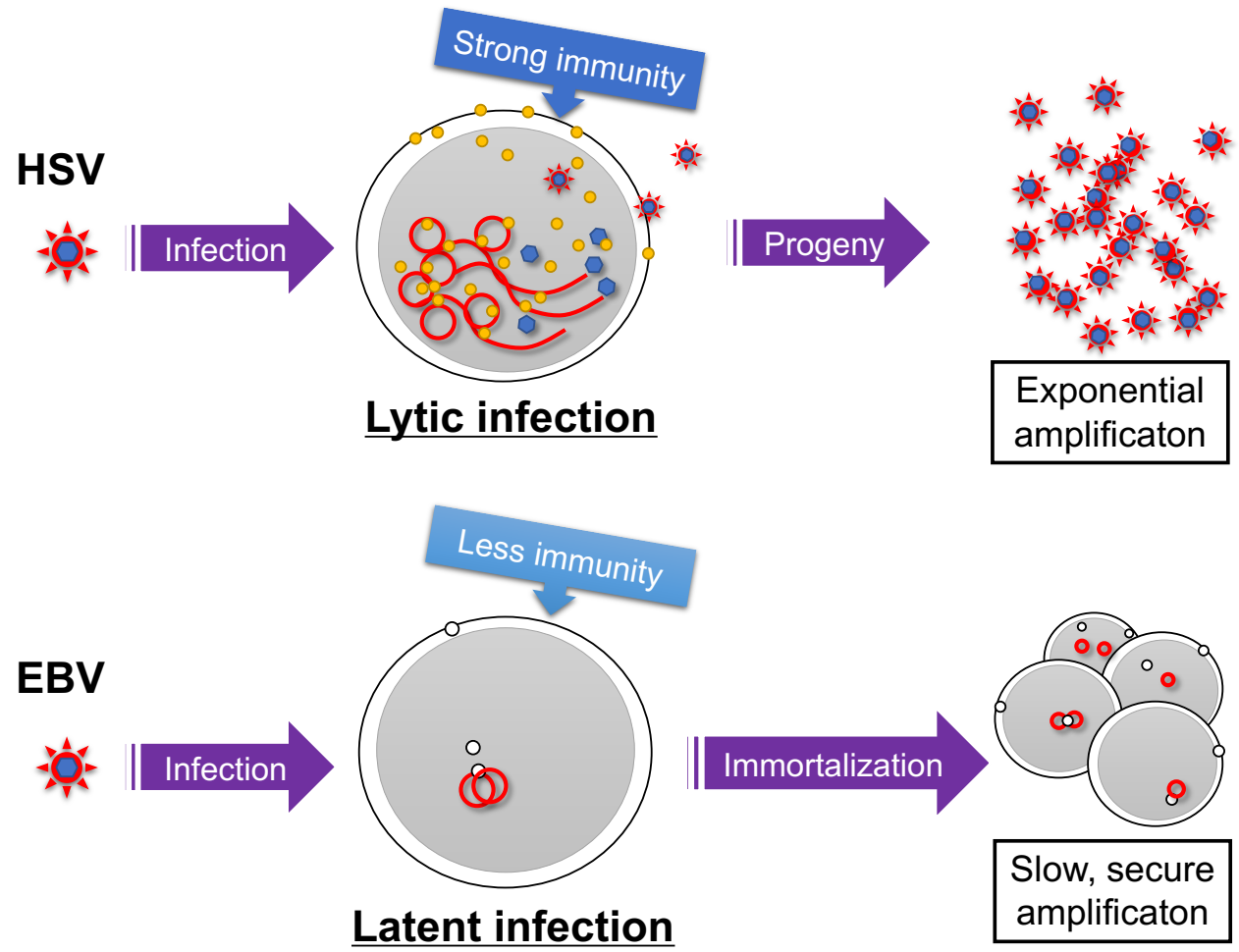

Figure 1. Survival strategies of herpesviruses. Infection of herpes simplex virus (HSV) causes lytic infection and the production of many progeny viruses, although the infected cells and virions may be targeted by the host immune reaction. Latent infection is maintained when the Epstein-Barr virus (EBV) infects a B cell, and the virus genome is amplified in synchronization with host cell amplification after immortalization. Red line indicates viral genome. Yellow and white circles represent viral lytic and latent gene products, respectively.

Although EBV predominantly establishes latent infection in primary B cells, closer observations have revealed that lytic genes are also expressed in addition to latent genes for several weeks upon de novo infection, yet productive viral DNA synthesis does not take place $[11,13]$. This period is called the pre-latent abortive lytic phase or, more simply, the pre-latent phase (Figure 2). The reason for lytic gene expression before establishment of 
latency is unclear, but it is possible that leaky expression of lytic genes during the pre-latent phase is beneficial for immortalization or evasion of cell death [14]. For example, EBV lytic genes include two anti-apoptotic BCL2 homolog genes (BALF1 and BHRF1) [15] and genes that downregulate human leukocyte antigen (HLA) gene expression (e.g., BNLF2A, BGLF5, BILF1, and BDLF3) [16]. The molecular mechanism of this pre-latent lytic gene expression is still elusive, but it may simply be accounted for by uncontrolled gene expression from the EBV genome, which lacks suppressive epigenetic modifications, such as CpG methylation. It may also be explained, at least partly, by the viral mRNAs incorporated into the virion [17], which can be released into cells upon infection.

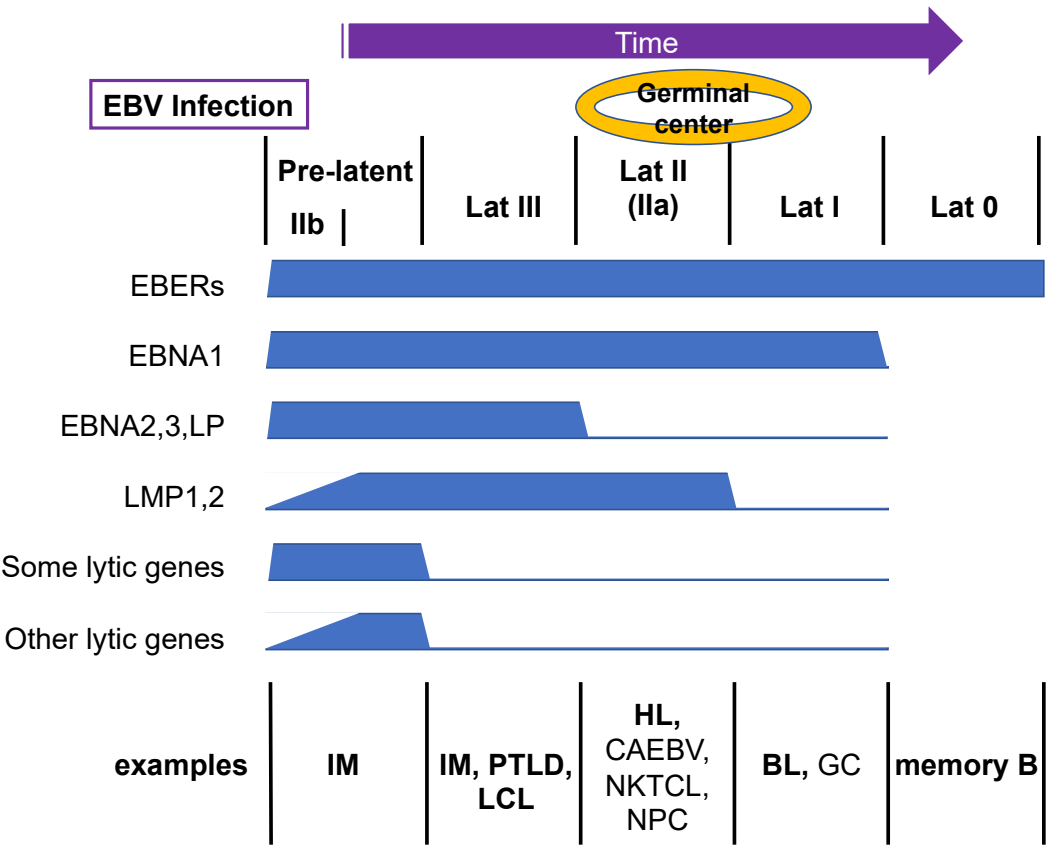

Figure 2. Transition of EBV gene expression upon primary B-cell infection. EBV infection of primary human $B$ cells triggers the expression of both latent and lytic viral genes, which is termed the prelatent phase. Subsequently, viral genes are silenced gradually. Example representative cells with the indicated patterns of viral gene expression in vivo are shown. Bold letters are B cells, and non-bold letters indicate non-B cells.

Immediately after infection of primary $B$ cells, the expression of six EBV nuclear antigen (EBNA) genes, EBNA1, 2, 3A, 3B, 3C, and LP, peaks, and the high levels are maintained for a long period $[18,19]$. The nature and functions of these EBV latent genes have been reviewed elsewhere [20]. A cluster of $\mathrm{W}$ promoters $(\mathrm{Wp})$ is activated to induce EBNAs upon infection. Each $W p$ is mapped to each component of internal repeat 1 (IR1), and thus $\mathrm{Wp}$ is present as multiple copies. In fact, Wp is vital for EBV because it is responsible for the expression of EBNA2, a transcriptional cofactor and master regulator of the reprogramming of the resting B-cell transcriptome (e.g., temporal induction of MYC) [21]. The Wp exhibits maximum activity in B cells [22], which is mediated by the B-cell-specific transcription factor PAX5 and CREB/ATF [23-25]. The high number of Wp (usually about 10 copies) enables high EBNA2 expression immediately after the entry of EBV into B cells [26]. EBNA2 expression causes repression of Wp and activation of the $C$ promoter (Cp) [27]. The physiological role of this switching of promoter usage is not understood, because the $\mathrm{Cp}$ is not required for B-cell growth transformation [28]. However, the $\mathrm{Cp}$ may be necessary in vivo. The $\mathrm{Cp}$ is located upstream of the $\mathrm{Wp}$ as a single copy and shows maximal activity in B cells [22]; this activity is mediated by EBNA2 and other factors, including OCT2, E2F, ARID3A, NF-Y, and SP1 [29,30].

Latent membrane proteins (LMPs), such as LMP1, 2A, and 2B, are expressed at low levels during the first few days after B-cell infection (Figure 2) [19,31]. The mechanism of 
initial suppression of LMP1 was long elusive [32], but MYC, which is induced immediately after B-cell infection by EBNA2, is responsible for LMP1 suppression [33]. Subsequently, the expression of LMPs gradually increases over a few weeks. This increase is mediated in part by EBNA2 [34,35], although other transcription factors, such as nuclear factor- $\mathrm{kB}$ (NF-kB), EBF1, PU.1, IRF7, and CREB/ATF, may also be involved [36-40]. Expression of LMP1 is important because LMP1 is a constitutively active oncogene of EBV. It mimics CD40 and elicits multiple signals, such as NF- $\mathrm{KB}$ and mitogen-activated protein kinase (MAPK), needed for cell growth and survival [41].

There seem to be two main expression patterns of lytic genes. The expression of several lytic genes, such as BHRF1, BOLF1, and BPLF1, is induced in high amounts immediately after infection, and those levels are maintained for weeks, similar to EBNAs, whereas the expression of other lytic genes increases gradually, reminiscent of LMPs (Figure 2) [19,42]. The reason for the different expression patterns of lytic genes is not clear, but it is possible that swiftly induced lytic genes are influenced by EBNA genes, given that they are frequently adjacent to each other. Thus, the first few days after EBV infection are characterized by low expression of LMPs and lytic genes, whereas EBNA genes are abundantly expressed, a pattern termed latency IIb (Figure 2) [31]. This pattern of EBV infection is observed in some B cells of IM patients. The pre-latent phase continues for weeks (or months) until the expression of lytic genes is silenced, and the virus establishes latency III, where latent genes are fully expressed and lytic genes are suppressed. Latency III cells can be seen in the presence of weak host-cell immunity, as seen in IM, PTLD, and the lymphoblastoid cell line (LCL) (Figure 2). LCL is a B cell line immortalized by infection of EBV.

\section{Restriction of Latent Genes}

If naïve B cells are infected with EBV, they move to germinal centers of the lymph nodes and spleen, where expression of EBNA2, EBNA3, and LP is suppressed to establish latency II (or IIa) (Figure 2). EBNA1-3 and LP are transcribed from the Cp in latency III, but the promoter is silenced and EBNA1 is instead expressed from the Qp in latency II. Because $\mathrm{Cp}$ activation is predominantly dependent on EBNA2 [43], the Cp is downregulated in association with decreased EBNA2. However, the trigger for decreased EBNA2 in germinal centers is unknown. Germinal center-specific transcriptional repressors, such as BCL6, may play a role in this process, because EBNA2 and BCL6 expression is inversely correlated [44]. Furthermore, treatment of latency III cells with IL-21 resulted in decreased Cp activity [45]. Because IL-21 induced BLIMP1 and OCT2, these factors may be involved in repression of the Cp. Although EBNA2, EBNA3, and LP are suppressed, LMP1, 2A, and 2B are expressed in latency II even in the absence of EBNA2. Cytokines, including IL-4, IL-6, IL-10, IL-13, and IL-21, have been implicated in EBNA2-independent expression of LMP1 [45-49], and the transcription factors NF-kB, AP-2, IRF7, C/EBP, and STAT in LMP1 promoter activation $[37-39,46,47,50,51]$. The HL, derived from B cells, typically shows this expression pattern. Some non-B-cell cancers, such as CAEBV, NKTCL, and NPC, also use this mode- $\mathrm{Wp} / \mathrm{Cp}$ is not active in cells other than $\mathrm{B}$ lymphocytes.

LMP1, LMP2A, and LMP2B can be silenced in BL and GC, which is termed latency I (Figure 2) [11]. The mechanism of this silencing is unclear, but because latency III cell lines can be isolated from latency I parental cell lines in cell culture, which lacks immune pressure, elimination of cells that express LMPs by host immunity likely plays a role in the process.

The mostly silenced mode is latency 0, in which only EBERs are expressed, in peripheral memory B cells (Figure 2) [11]. The mechanism of this silencing of EBNA1 is not known, but host immunity may be involved.

\section{Reactivation from Latency}

Reactivation of EBV can be induced in cultured cells by chemical reagents, such as phorbol ester, calcium ionophore, histone deacetylase (HDAC) inhibitors, and DNA 
methylase inhibitors, and by biological stimulation through transforming growth factor $\beta$ (TGF- $\beta$ ), anti-immunoglobulin, hypoxia, reactive oxygen species, and temperature shifts (Figure 3) [52-54]. Although the trigger is unknown, EBV reactivation can occur in response to a variety of stimuli (Figure 3).

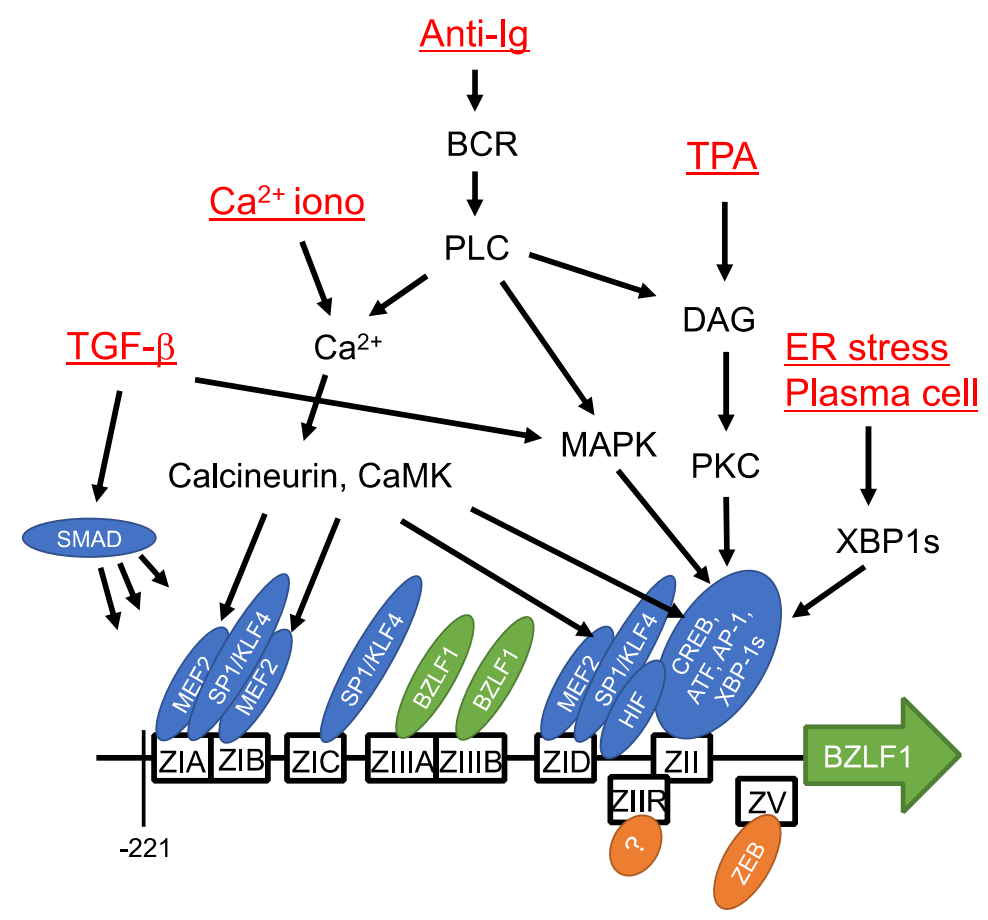

Figure 3. Cis- and trans-acting elements of BZLF1 promoter and signaling pathways. Cis-acting elements of the BZLF1 promoter sequence sufficient for induction in response to lytic stimuli are depicted as boxes. Transcription factors that bind the elements are indicated by ellipses. Inducing reagents/stimuli and signaling molecules are also shown. Modified from [54].

EBV encodes two immediate-early (IE) genes, BZLF1 (also known as Z, Zta, ZEBRA, or EB1) and BRLF1 (R or Rta) [55]. Expression of the IE genes is suppressed in the latent phase but accelerated by inducing reagents or stimulation. BZLF1 and BRLF1 are tandemly and adjoiningly mapped in the EBV genome near the EBNA1 gene. The fact that these IE genes are situated within the intron sequence of EBNA1 in a complementary orientation is interesting, because HSV LAT is complementary to ICP0.

BZLF1 is a viral transcription factor, similar to host AP- 1 and CREB, and has a basic leucine zipper (bZip) motif [56,57]. It forms a homodimer via the bZip motif, binds to DNA and induces transcription of viral downstream genes [58]. BZLF1 binds to binding motif similar to AP-1, called BZLF1-responsive element (ZRE), which are abundant in the promoters of viral lytic genes, especially early genes, and induces transcription $[59,60]$. Uniquely, this transcription factor binds to CpG-methylated DNA [61-63]. This enables BZLF1 to activate transcription of the viral lytic genes silenced by CpG methylation in latent cells. In addition, BZLF1 functions as an origin of lytic replication (ori-Lyt) binding protein in lytic viral DNA synthesis [64]. By contrast, BRLF1 is a transcriptional activator that acts in three ways [55]. First, it binds directly to BRLF1-responsive element (RRE) of promoter and activates transcription as a transcription factor $[65,66]$. Second, it is a transcriptional co-factor that binds indirectly to GC-rich motifs by binding to other cellular transcription factors, such as SP1 and OCT-1 $[67,68]$. Third, it regulates signaling pathways, such as MAPK and phosphatidylinositol 3-kinase (PI3K) [69,70]. Both IE genes are essential for lytic reactivation, because the lytic cycle is blocked by knockout of either gene. Furthermore, exogenous overexpression of BZLF1 or BRLF1 in latently infected cells can trigger lytic reactivation. BRLF1, but not BZLF1, is needed for EBV reactivation in EBV-positive normal 
oral keratinocytes [8]. However, BZLF1 is presumed to be more important because more efficient reactivation can be achieved by exogenous expression of BZLF1 than of BRLF1, at least in many cell lines.

Expression of BZLF1 is regulated at the transcriptional level. Therefore, research has focused on the BZLF1 promoter sequence (Figure 3). Reporter assays showed that a short sequence in the BZLF1 promoter $(-221$ to +12$)$ was sufficient for its activation by 12-O-tetradecanoylphorbol-13-acetate (TPA) [71] and anti-immunoglobulin [72] (Figure 3). This short promoter sequence consists of four copies of ZI, and one ZII and two ZIII motifs. ZIA, B, and D are bound by MEF2 family transcription factors and ZIA, C, and D are bound by SP1/KLF4 [73-75]. MEF2 is a negative regulator bound to the promoter in latency; it activates the promoter in response to calcium signaling. SP1/3 proteins are ubiquitous host transcription factors and their stable binding to ZIA, C, and D underscores the basal activity of the BZLF1 promoter [73]. KLF-family transcription factors have similar consensus binding motifs to SP1. KLF4 binds and activates the BZLF1 promoter [75] in a differentiation-dependent manner [76]. The sequence of the ZII domain is similar to the consensus binding sequence of CREB and AP-1, and is bound by a range of bZip transcription factors $[71,77,78]$ needed for promoter activation by various stimuli. XBP-1 protein is inactive unless activated by splicing upon endoplasmic reticulum (ER) stress, and the spliced form of XBP-1 (XBP-1s) is associated with plasma cell differentiation. XBP-1s binds to the ZII element and activates the BZLF1 promoter [77]. Once produced, BZLF1 protein, as a viral transcription factor, activates its own promoter by binding to the ZIIIA and B domains [79]. HIF-1 binds to hypoxia-response element (HRE) between ZID and ZIIR, triggering BZLF1 promoter activation [80]. The BZLF1 promoter is activated by TGF- $\beta$ via MAPK signaling, as well as by binding of SMAD [81].

Two major cis-acting elements are crucial for negative regulation of the BZLF1 promoter (Figure 3). ZEB1/2 proteins bind to the $\mathrm{ZV}$ and $\mathrm{ZV}^{\prime}$ domains located around the transcriptional start site of BZLF1 and suppress transcription of BZLF1 [82,83]. The ZIIR element, located between ZID and ZII, is a strong silencer of the promoter $[84,85]$, although the ZIIR-binding protein has not yet been identified. Other suppressive factors recently identified include MYC and KAP1 [86,87].

The BRLF1 promoter is activated by transcription factors, such as SP1, EGR1, BLIMP1, NF1, and BZLF1, and suppressed by YY1 and ZEB [61,88-92].

When IE genes are expressed at a certain level, these transcriptional activators induce transcription of viral early genes (Figure 4). Among the early class genes, BMLF1/BSLF2 (also named SM, Mta, and EB2), the homolog of HSV ICP27, encodes an essential protein involved in viral gene expression by affecting multiple processes, including RNA metabolism, transcription, and translation [93-100]. Other early gene products include enzymes involved in nucleotide metabolism, such as thymidine kinase (TK) and ribonucleotide reductase (RR), which presumably play supportive roles, especially in resting cells (Table 3). In addition to six essential viral replication genes (BALF5, BMRF1, BALF2, BBLF4, BSLF1, BBLF2/3), BKRF3 (uracilDNA glycosylase) and BZLF1 (oriLyt-binding protein) have also been identified to be crucial for replication [64,101-103] (Table 3). These viral factors trigger viral DNA replication in the replication compartment of the nucleus [64]. After viral DNA replication, a complex of viral gene products, dubbed the viral preinitiation complex (vPIC), mediates late gene expression from the amplified viral DNA [104-110] (Table 4). Basically, this complex recognizes two features of DNA; TATT motif instead of TATA at the promoter, and lack of epigenetic modifications, such as methylation. The TATT motif is specifically found in the late gene promoters and one of the vPIC, BcRF1, recognizes the motif. Lack of epigenetic marks is an earmark of newly synthesized viral DNA. 


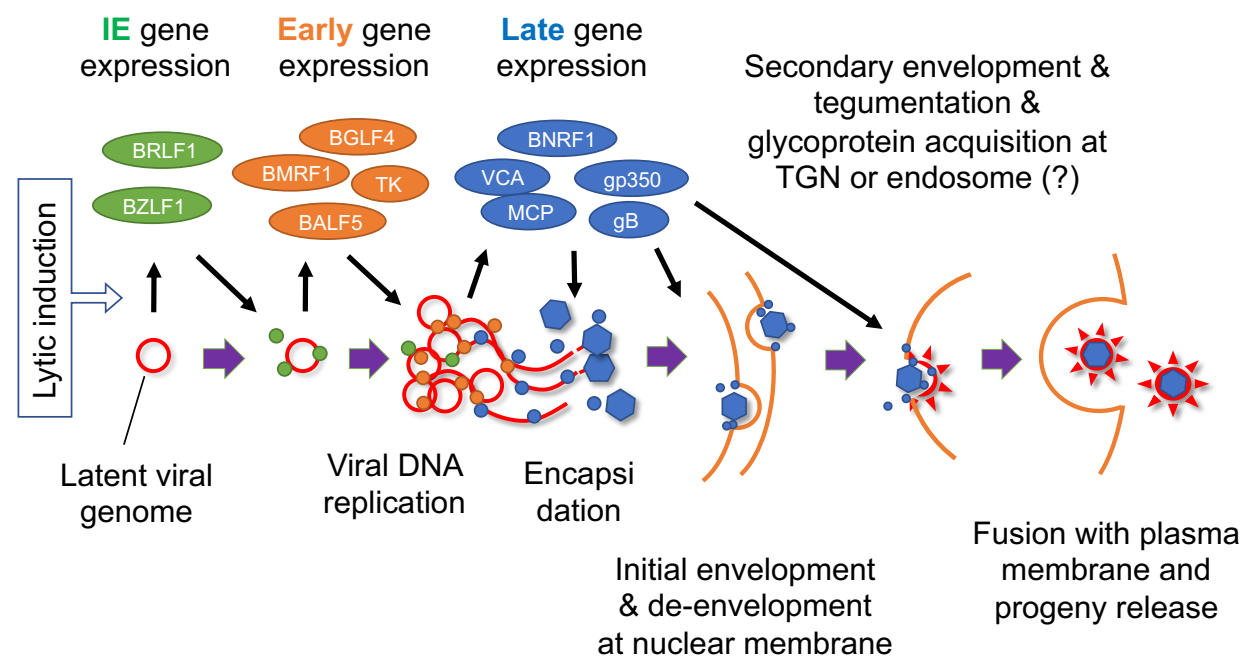

Figure 4. Schematic diagram of EBV lytic cycle. Lytic induction results in a coordinated cascade of viral gene expression and viral DNA replication, followed by encapsidation, envelopment, and progeny production. Red line indicates viral genome. Green, orange, and blue circles represent viral IE, early, and late gene products, respectively. TGN, trans-Golgi network. Modified from [111].

Table 3. Herpesviral genes involved in viral lytic DNA synthesis.

\begin{tabular}{|c|c|c|c|c|}
\hline EBV & Necessity \# & HSV & HCMV & Function \\
\hline BZLF1 * & essential & UL9 * & UL84* & oriLyt-binding \\
\hline BALF5 & essential & UL30 & UL54 & polymerase catalytic subunit (Pol) \\
\hline BMRF1 & essential & UL42 & UL44 & processivity subunit of polymerase \\
\hline BALF2 & essential & UL29 & UL57 & $\begin{array}{l}\text { single-stranded DNA-binding protein } \\
\text { (ssDNABP) }\end{array}$ \\
\hline BBLF4 & essential & UL5 & UL105 & helicase \\
\hline BSLF1 & essential & UL52 & UL70 & primase \\
\hline BBLF2/3 & essential & UL8 & UL102 & primase-binding protein \\
\hline BKRF3 & essential & UL29 & UL114 & $\begin{array}{c}\text { uracil-DNA glycosylase, involved in DNA } \\
\text { repair }\end{array}$ \\
\hline BXLF1 & supportive & UL23 & - & thymidine kinase (TK) \\
\hline BORF2 & supportive & UL39 & UL45 & ribonucleotide reductase (RR) large subunit \\
\hline BaRF1 & supportive & UL40 & - & ribonucleotide reductase (RR) small subunit \\
\hline BLLF3 & supportive & UL50 & UL72 & $\begin{array}{l}\text { deoxyuridine triphosphate } \\
\text { nuclotidohydrolase (dUTPase) }\end{array}$ \\
\hline
\end{tabular}

* These genes share the function, but have no sequential homology. \# Necessity for EBV lytic replication.

Table 4. vPIC genes of EBV, KSHV, and HCMV.

\begin{tabular}{ccc}
\hline EBV & HCMV & Presumed Function and/or Nature \\
\hline BCRF1 & UL87 & TATT-binding protein, associates with RNAPII \\
BDLF3.5 & UL91 & stabilized by phosphorylation \\
BDLF4 & UL92 & DNA-binding protein, having potential \\
BFRF2 & UL49 & zinc-finger domain \\
BGLF3 & UL95 & $\begin{array}{c}\text { hub of vPIC, phosphorylation increased } \\
\text { association with BFRF2 and BVLF1 } \\
\text { elongation factor (in HCMV) }\end{array}$ \\
\hline
\end{tabular}

Late genes include many viral structural genes, such as major capsid protein (MCP), viral capsid antigen (VCA), major tegument protein (BNRF1), and glycoproteins (gB and gp350). Encapsidation takes place in the nucleus, and the nucleocapsid is transported to the cytoplasm through the nuclear membrane, a process in which two viral proteins, 
BFRF1 and BFLF2, and other viral and cellular factors are involved [112]. During this nuclear egress, the nucleocapsid must twice cross the lipid bilayer membrane. The nucleocapsid buds into the inner nuclear membrane to obtain an envelope (primary or initial envelopment), which is removed by fusion with the outer nuclear membrane. The naked nucleocapsid next buds into a membranous organelle in the cytoplasm (possibly the transGolgi network (TGN), endosome, or a related organelle). Tegument components are also incorporated at this step of secondary envelopment. Finally, fusion of the organelle with the plasma membrane releases mature progeny virions. The functions of EBV lytic genes are summarized elsewhere [113].

\section{Epigenetic Regulation of Latency Establishment}

The episomal EBV genome in latently infected cells is modified by CpG methylation and assembled with histones to form a chromatin structure. However, EBV genome DNA in the viral nucleocapsid is devoid of epigenetic marks, such as histones and CPG methylation (Figure 5) [114-116]. When primary B cells are infected with EBV, the EBV genome is first chromatinized by histone assembly, followed by histone modification, for example of histone H3 K27 trimethylation (H3K27me3) and H3K9me3 [117]. Those suppressive histone modifications restrict EBV gene expression but permit leaky expression of many viral genes, which is recognized as lytic gene expression in the pre-latent phase. Suppressive histone modifications, such as H3K27me3, H4K20me3 and H3K9me3, during the pre-latent phase are not sufficient for complete suppression of viral genes, likely because the viral genome is associated with activating histone modifications, such as histone H3K4me3 and acetylation (Figure 5). Interestingly, the major tegument protein BNRF1 associates with histone chaperone molecules upon infection of primary $B$ cells and increases the active histone mark, H3K4me3, on the viral genome [118]. In addition to those histone lysine methylations, a series of reports have indicated that arginine methyltransferases, especially PRMT5, play an important role in transformation [119-122]. After histone modifications, CpG methylation of viral DNA occurs, over weeks to months [116]. After completion of CpG methylation, viral lytic gene expression is strongly suppressed (Figure 5).

In contrast to viral genome chromatinization, suppressive histone markers and $\mathrm{CpG}$ methylation of the host genome are disrupted when primary B cells are infected, and gradually restored thereafter [123-125]. However, even in established LCL, CpG methylation of the host genome is significantly lower compared to that in primary B cells (Figure 5). It is speculated that immediate collapse of host genome CpG methylation upon infection is needed for overexpression of the key host genes for growth transformation.

The situation is different in epithelial cells. Viral genomic DNA starts to be CpGmethylated as early as day 11 and is completed by day 17 after infection of an immortalized normal gastric epithelial cell line. Demethylation of the host genome is not detected in the epithelial cell line.

Instead, CpG methylation takes place from day 17 to 28 , a period associated with decreased expression of genes involved in tumor suppression and cell differentiation [126]. It is assumed that, in epithelial cells, suppressive histone modifications also take place before CpG DNA methylation, as in B cells [127]. The reason why large-scale host genome CpG demethylation does not occur in epithelial cells is unclear, but differences in the cell cycle may account for delayed CpG methylation of EBV genome DNA in B lymphocytes. Primary $B$ cells used in such experiments are in $G_{0}$ phase and thus completely growth-halted, whereas the epithelial cells used are established cell lines or immortalized normal epithelial cell lines. In resting cells, gene expression is generally suppressed to a minimal level by CpG methylation, but immortalized cells must express genes that support proliferation. 


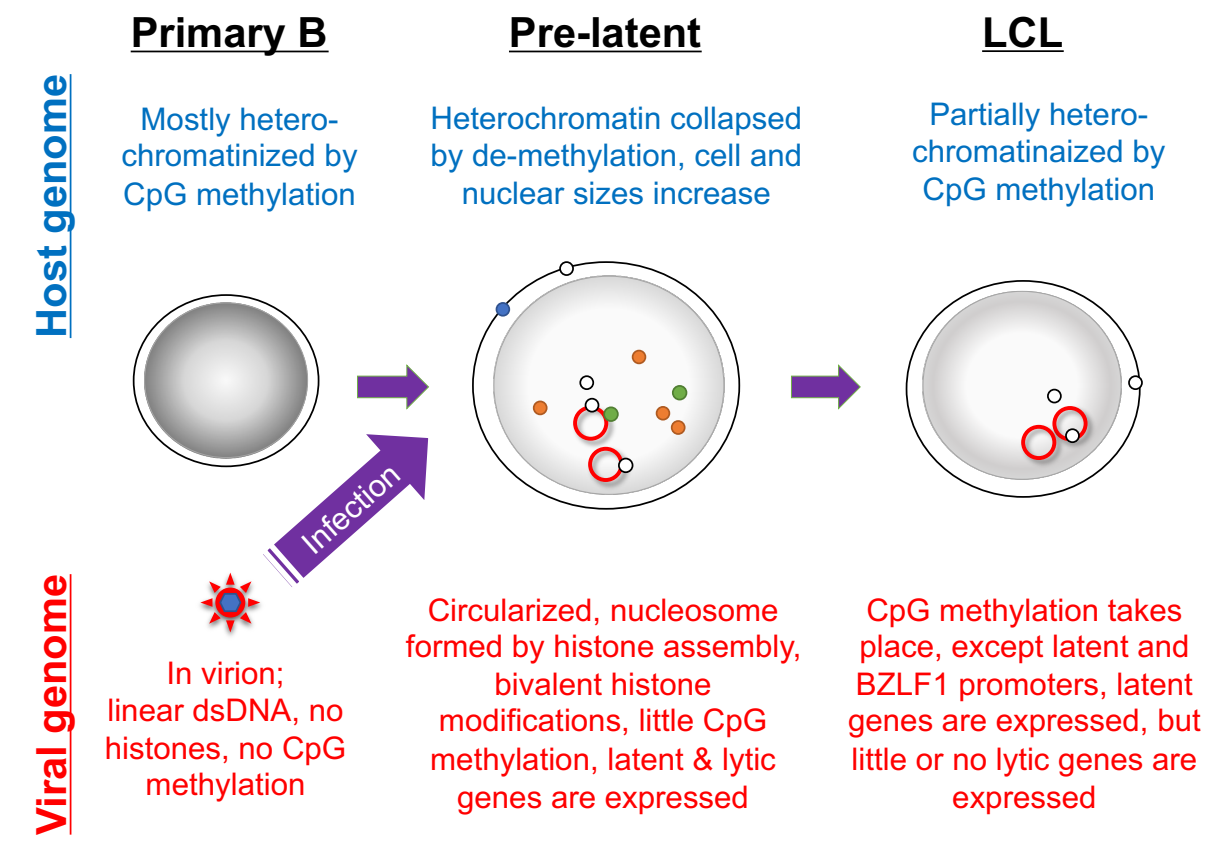

Figure 5. Morphology and epigenetic state of primary B cells infected with EBV. The EBV genome in virions is devoid of nucleosome structure and CpG DNA methylation, but is modified by histones and $\mathrm{CpG}$ methylation in infected cells. The host cell morphology and genome are significantly influenced by EBV infection. The red line indicates latent viral genome. Dark gray shadows in nuclei indicate strong heterochromatinization. Green, orange, and blue circles represent viral lytic gene products, and white circles represent viral latent gene products.

EBV super-enhancers are clusters of enhancers dense with transcription factors and cofactors, and mediate strong activation of specific genes that regulate cell identity and fate [128]. EBV super-enhancers are typically composed of EBNA2, EBNA-LP, EBNA3A, EBNA3C, NF- $\kappa$ B, and RBPJ $\kappa$, and are associated with a high level of histone acetylation $[129,130]$. Chromatin loop structures are formed by CTCF and assembling enhancers, with which RNAPII is frequently associated. Induction of critical host genes, such as MYC, BCL2, IRF4, MCL1, EBF, and RUNX3, in primary B-cell infection is dependent on EBV super-enhancers [129-132].

\section{Epigenetic Regulation of Latent Gene Restriction}

Silencing of viral genes in infected cells by histone modification and CpG methylation is not a complicated concept. However, the maintenance of latency must be intricately regulated, because only a handful of appropriate latent genes should be expressed efficiently while other latent and lytic genes must be silenced. Excessive transcription of improper genes in an inappropriate context, or insufficient expression of necessary genes, would negatively affect the infected cells and virus genome. Moreover, the density of genes in the EBV genome is high (about 80 genes in $175 \mathrm{~kb} ; 2.2 \mathrm{~kb}$ per gene), in comparison to the human genome (about 20,000 genes in 3,000,000 kb; 150 kb per gene). In this respect, CpG methylation of particular promoters plays a primary role. For example, Wp/Cp/Qp activity is inversely correlated with CpG methylation level of the promoter [114,133-140]. The LMP1 promoter is also regulated by CpG methylation [114,135,141,142]. TET2, which mediates the conversion of methylated $\mathrm{CpG}$ into hydroxymethylcytosine, ultimately leading to CpG demethylation, increases the expression of EBNAs and LMPs $[143,144]$. Furthermore, a component of polycomb repressive complex 1 (PRC1) and DNA methyltransferase (DNMT) enzymes are crucial for the suppression of EBNAs and LMPs [145]. These reports demonstrate the importance of $\mathrm{CpG}$ methylation in fine-tuning viral latent gene expression.

Heterochromatin tends to expand the suppressive region to neighboring euchromatin sequences. Therefore, once a part of the viral genome has been silenced by CpG methyla- 
tion, the methylation may spread to neighboring promoters, which could be needed for maintenance of EBV latency. To block the ripple of suppression, however, EBV uses a host insulator protein, CTCF $[146,147]$. Qp must be kept active in latency I and II to mediate the expression of EBNA1 when $\mathrm{Wp} / \mathrm{Cp}$ and other lytic promoters are silenced by $\mathrm{CpG}$ methylation. CTCF protein binds upstream of $\mathrm{Qp}$ and prevents suppressive epigenetic modifications, such as histone $\mathrm{H} 3 \mathrm{~K} 9 \mathrm{me} 3$ and $\mathrm{CpG}$ methylation, thereby sustaining high promoter activity [148]. Moreover, analysis of the 3D organization of latent viral genome revealed that CTCF binding does not act as a simple epigenetic insulator. In complex with the host factor Cohesion, CTCF mediates loop formation of the viral genome in infected cells, which influences the epigenetic state and thereby alters gene expression. In latency I, CTCF/Cohesion mediates chromatin-loop formation between the origin of plasmid replication (OriP) and Qp, and increases Qp activity possibly via OriP-bound factors, EBNA1, and chromatin-remodeling factors, such as ORC and SNF2h [149]. In latency III, OriP forms a chromatin loop with the Cp and LMP1 promoters via CTCF/Cohesion, and EBNA1 and chromatin remodeling factors at the OriP mediate activation of $\mathrm{Cp}$ and the LMP1 promoter [149-151].

The silencing of latent genes is associated with higher levels of suppressive histone modification, such as histone H3K9me3 and H3K27me3 [152,153]. Appropriate transcriptional activation of latent gene promoters, including $\mathrm{Cp} / \mathrm{Wp} / \mathrm{Qp}$ and LMP promoters, is mediated by active histone marks, such as histone acetylation and H3K4me3 [151,153].

\section{Epigenetic Regulation of Reactivation}

Although almost all EBV lytic genes are silenced by CpG methylation in EBV-positive cell lines, CpG DNA methylation of the BZLF1 promoter is maintained at a low level, like those of latent promoters such as the Qp and LMP1 promoters $[63,75,114]$. Few CpG dinucleotides are present in the BZLF1 promoter, whereas CpG dinucleotides are denser in other latent and lytic promoters, including the BRLF1 promoter $[63,75]$. Therefore, it is assumed that BZLF1 transcription is not primarily silenced by CpG methylation in cell culture. Alternatively, the BZLF1 promoter is silenced by suppressive histone modifications, such as H3K27me3 and H3K9me3 [63,154-156]. Silencing of the BZLF1 promoter by histone methylation rather than $\mathrm{CpG}$ methylation is essential for prompt induction in response to lytic stimuli. These suppressive histone methylations are rapidly demethylated, but methyl-CpG is a stable mark that requires multistep demethylation (hydroxymethylcytosine formation, followed by glycosylase reaction and base excision repair, or de novo DNA synthesis) [157]. Moreover, the BZLF1 promoter is modified not only by suppressive, but also by activating, histone modifications [155,156], generating bivalent chromatin [158]. Therefore, the BZLF1 promoter is capable of activating the transcription of BZLF1 at any time. BZLF1 protein binds CpG-methylated DNA motifs and induces transcription of downstream viral genes [61-63]. These unique properties make BZLF1 a key factor for EBV reactivation from latency.

CPG DNA methylation of the viral genome is eliminated by de novo viral genome replication [114]. vPIC mediates viral late gene transcription only from unmethylated DNA, which is why late gene expression occurs after viral DNA synthesis [159].

\section{Involvement of Lytic Genes in Oncogenesis}

It was previously speculated that only latent genes (not lytic genes) were involved in the oncogenesis of EBV-associated cancers, because lytic genes were not readily detectable in those cancers. However, it is now understood that lytic genes are also expressed to some extent in cancer cells. Lytic genes of EBV are implicated in oncogenesis [14,160-164]. For example, in cell culture, pre-latent lytic gene expression contributes to B-cell transformation $[116,165]$. EBV in NPC has been shown to frequently express lytic genes and such lytic genes play an important role in oncogenesis [164]. EBV in CAEBV and other lymphomas, such as NKTCL and DLBCL, frequently has intragenic deletions, which presumably caused more lytic gene expression and tumor formation [163,166,167]. When humanized mice 
are infected with BZLF1-kockout EBV, tumors develop less frequently than in wild-type control EBV [168]. Knockout of BZL1 results in restriction of BZLF1 and other downstream lytic genes; thus, these lytic genes likely contribute to tumor development. By contrast, mutation of two repressive cis-acting elements, ZIIR and ZV, results in increased expression of BZLF1 and other lytic genes without viral DNA synthesis, and increased lymphoma formation [169].

Clinically oriented approaches have also been adopted. Two independent sequence analyses identified a nucleotide variation in the BZLF1 promoter region of EBV in NPC and lymphoma specimens $[170,171]$, and this variant accumulated in BL and gastric carcinoma [172]. Introduction of this variation increased lytic gene expression [172]. The EBV genome in lymphoma specimens frequently bears an intragenic deletion in the BART region $[167,173,174]$, the deletion of which upregulated lytic gene expression and promoted tumor formation in a humanized mouse model [175]. Essential lytic genes, such as viral DNA polymerase BALF5, are deleted in EBV-positive lymphomas, promoting a lytic phenotype and lymphomagenesis in mice [167].

Although the molecular mechanism by which the EBV lytic cycle contributes to oncogenesis is unknown, some lytic genes likely promote cancer formation. BCL2 homolog genes of EBV (BALF1 and BHRF1) protect infected cells from death [15]. BNLF2A, BGLF5, BILF1, and BDLF3 downregulate HLA and thereby protect infected cells from immunity [16]. BRLF1, BNRF1, BALF3, BGLF4, and BGLF5 have been implicated in genome instability [164]. These factors can confer advantages for infected cells. In addition, the proliferation of cells surrounding EBV-infected cells may be promoted. For example, production of the EBV homolog of IL-10, BCRF1, increases surrounding B-cell proliferation [176]. The lytic switch transcription factor BZLF1 enhances the production of cytokines, such as IL-6, IL-8, IL-10, IL-13, and VEGF [111], and increases the proliferation of surrounding cells.

\section{Conclusions}

Here, the life cycle of EBV and molecular basis thereof were summarized. EBV has established a complex life cycle that maximizes survival potential. Despite our immune system, humans cannot eliminate EBV from the body. To prevent EBV-associated disorders, which are not particularly rare, preventative and therapeutic measures are needed. Using its delicate life cycle of EBV against itself, disturbing viral gene expressions may provide possibility to interrupt EBV persistence and repress formation and maintenance of tumors. For example, our group has tried to suppress expression of viral oncogene LMP1 by HSP90 inhibitors to decrease CAEBV and NKTCL tumor growth $[177,178]$. Effects of epigenetic modifiers, such as HDAC inhibitors [179,180] and DNMT inhibitors [181,182], are also expected, especially for lytic induction therapy [183-185]. Further studies are needed, however, for such practical use.

Author Contributions: Writing—original draft preparation, T.M.; writing—review and editing, T.M., A.S., T.I., Y.Y., T.W., Y.S., H.K.; visualization, T.M.; supervision, H.K., T.M.; funding acquisition, T.M. All authors have read and agreed to the published version of the manuscript.

Funding: This work was supported by grants-in-aid for Scientific Research form the Ministry of Education, Culture, Sports, Science and Technology (19K0750), Japan Agency for Medical Research and Development (AMED) (JP20wm0325012), and the Takeda Science Foundation.

Institutional Review Board Statement: Not applicable.

Informed Consent Statement: Not applicable.

Data Availability Statement: Not applicable.

Acknowledgments: We thank Yusuke Okuno, Teru Kanda, Hironori Yoshiyama, and Tatsuya Tsurumi for discussions.

Conflicts of Interest: The authors declare no conflict of interest. 


\section{References}

1. Young, L.S.; Yap, L.-F.; Murray, P.G. Epstein-Barr virus: More than 50 years old and still providing surprises. Nat. Rev. Cancer 2016, 16, 789-802. [CrossRef]

2. Dunmire, S.K.; Hogquist, K.A.; Balfour, H.H. Infectious Mononucleosis. Curr. Top. Microbiol. Immunol. 2015, 390, 211-240. [PubMed]

3. Cohen, J.I. Epstein-Barr virus infection. N. Engl. J. Med. 2000, 343, 481-492. [CrossRef]

4. Kenney, S.C. Reactivation and lytic replication of EBV. In Human Herpesviruses: Biology, Therapy, and Immunoprophylaxis; Arvin, A., Campadelli-Fiume, G., Mocarski, E., Moore, P.S., Roizman, B., Whitley, R., Eds.; Cambridge University Press: Cambridge, UK, 2007.

5. Shannon-Lowe, C.; Rickinson, A. The Global Landscape of EBV-Associated Tumors. Front. Oncol. 2019, 9, 713. [CrossRef] [PubMed]

6. Cohen, J.I. Herpesvirus latency. J. Clin. Investig. 2020, 130, 3361-3369. [CrossRef]

7. Thorley-Lawson, D.A. EBV Persistence-Introducing the Virus. Curr. Top. Microbiol. Immunol. 2015, 390, 151-209. [PubMed]

8. Wille, C.K.; Nawandar, D.M.; Panfil, A.R.; Ko, M.M.; Hagemeier, S.R.; Kenney, S.C. Viral Genome Methylation Differentially Affects the Ability of BZLF1 versus BRLF1 To Activate Epstein-Barr Virus Lytic Gene Expression and Viral Replication. J. Virol. 2013, 87, 935-950. [CrossRef]

9. Temple, R.M.; Zhu, J.; Budgeon, L.; Christensen, N.D.; Meyers, C.; Sample, C.E. Efficient replication of Epstein-Barr virus in stratified epithelium in vitro. Proc. Natl. Acad. Sci. USA 2014, 111, 16544-16549. [CrossRef]

10. Yoshiyama, H.; Shimizu, N.; Takada, K. Persistent Epstein-Barr virus infection in a human T-cell line: Unique program of latent virus expression. EMBO J. 1995, 14, 3706-3711. [CrossRef]

11. Murata, T.; Sato, Y.; Kimura, H. Modes of infection and oncogenesis by the Epstein-Barr virus. Rev. Med Virol. 2014, 24, $242-253$. [CrossRef]

12. Kalla, M.; Göbel, C.; Hammerschmidt, W. The Lytic Phase of Epstein-Barr Virus Requires a Viral Genome with 5-Methylcytosine Residues in CpG Sites. J. Virol. 2012, 86, 447-458. [CrossRef]

13. Inagaki, T.; Sato, Y.; Ito, J.; Takaki, M.; Okuno, Y.; Yaguchi, M.; Al Masud, H.M.A.; Watanabe, T.; Sato, K.; Iwami, S.; et al. Direct Evidence of Abortive Lytic Infection-Mediated Establishment of Epstein-Barr Virus Latency During B-Cell Infection. Front. Microbiol. 2021, 11, 575255. [CrossRef]

14. Rosemarie, Q.; Sugden, B. Epstein-Barr Virus: How Its Lytic Phase Contributes to Oncogenesis. Microorganisms 2020, 8, 1824. [CrossRef] [PubMed]

15. Altmann, M.; Hammerschmidt, W. Epstein-Barr Virus Provides a New Paradigm: A Requirement for the Immediate Inhibition of Apoptosis. PLoS Biol. 2005, 3, e404. [CrossRef]

16. Quinn, L.L.; Williams, L.R.; White, C.; Forrest, C.; Zuo, J.; Rowe, M. The Missing Link in Epstein-Barr Virus Immune Evasion: The BDLF3 Gene Induces Ubiquitination and Downregulation of Major Histocompatibility Complex Class I (MHC-I) and MHC-II. J. Virol. 2016, 90, 356-367. [CrossRef] [PubMed]

17. Jochum, S.; Ruiss, R.; Moosmann, A.; Hammerschmidt, W.; Zeidler, R. RNAs in Epstein-Barr virions control early steps of infection. Proc. Natl. Acad. Sci. USA 2012, 109, E1396-E1404. [CrossRef] [PubMed]

18. Price, A.M.; Luftig, M.A. Dynamic Epstein-Barr virus gene expression on the path to B-cell transformation. Adv. Virus Res. 2014, 88, 279-313. [CrossRef]

19. Wang, C.; Li, D.; Zhang, L.; Jiang, S.; Liang, J.; Narita, Y.; Hou, I.; Zhong, Q.; Zheng, Z.; Xiao, H.; et al. RNA Sequencing Analyses of Gene Expression during Epstein-Barr Virus Infection of Primary B Lymphocytes. J. Virol. 2019, 93, e00226-19. [CrossRef] [PubMed]

20. Kanda, T. EBV-Encoded Latent Genes. Adv. Exp. Med. Biol. 2018, 1045, 377-394. [CrossRef]

21. Kempkes, B.; Ling, P.D. EBNA2 and Its Coactivator EBNA-LP. Curr. Top. Microbiol. Immunol. 2015, 391, 35-59. [CrossRef]

22. Contreras-Brodin, B.; Karlsson, A.; Nilsson, T.; Rymo, L.; Klein, G. B cell-specific activation of the Epstein-Barr virus-encoded C promoter compared with the wide-range activation of the W promoter. J. Gen. Virol. 1996, 77, 1159-1162. [CrossRef] [PubMed]

23. Kirby, H.; Rickinson, A.; Bell, A. The activity of the Epstein-Barr virus BamHI W promoter in B cells is dependent on the binding of CREB/ATF factors. J. Gen. Virol. 2000, 81, 1057-1066. [CrossRef]

24. Tierney, R.; Kirby, H.; Nagra, J.; Rickinson, A.; Bell, A. The Epstein-Barr Virus Promoter Initiating B-Cell Transformation Is Activated by RFX Proteins and the B-Cell-Specific Activator Protein BSAP/Pax5. J. Virol. 2000, 74, 10458-10467. [CrossRef] [PubMed]

25. Tierney, R.; Nagra, J.; Hutchings, I.; Shannon-Lowe, C.; Altmann, M.; Hammerschmidt, W.; Rickinson, A.; Bell, A. Epstein-Barr Virus Exploits BSAP/Pax5 To Achieve the B-Cell Specificity of Its Growth-Transforming Program. J. Virol. 2007, 81, 10092-10100. [CrossRef] [PubMed]

26. Tierney, R.J.; Kao, K.Y.; Nagra, J.K.; Rickinson, A.B. Epstein-Barr virus BamHI W repeat number limits EBNA2/EBNA-LP coexpression in newly infected B cells and the efficiency of B-cell transformation: A rationale for the multiple $\mathrm{W}$ repeats in wild-type virus strains. J. Virol. 2011, 85, 12362-12375. [CrossRef]

27. Woisetschlaeger, M.; Jin, X.W.; Yandava, C.N.; Furmanski, L.A.; Strominger, J.L.; Speck, S.H. Role for the Epstein-Barr virus nuclear antigen 2 in viral promoter switching during initial stages of infection. Proc. Natl. Acad. Sci. USA 1991, 88, 3942-3946. [CrossRef] [PubMed] 
28. Mabuchi, S.; Hijioka, F.; Watanabe, T.; Yanagi, Y.; Okuno, Y.; Al Masud, H.M.A.; Sato, Y.; Murata, T.; Kimura, H. Role of Epstein-Barr Virus C Promoter Deletion in Diffuse Large B Cell Lymphoma. Cancers 2021, 13, 561. [CrossRef]

29. Borestrom, C.; Forsman, A.; Ruetschi, U.; Rymo, L. E2F1, ARID3A/Bright and Oct-2 factors bind to the Epstein-Barr virus C promoter, EBNA1 and oriP, participating in long-distance promoter-enhancer interactions. J. Gen. Virol. 2012, 93, $1065-1075$. [CrossRef] [PubMed]

30. Boreström, C.; Zetterberg, H.; Liff, K.; Rymo, L. Functional Interaction of Nuclear Factor Y and Sp1 Is Required for Activation of the Epstein-Barr Virus C Promoter. J. Virol. 2003, 77, 821-829. [CrossRef]

31. Price, A.M.; Luftig, M.A. To Be or Not Ilb: A Multi-Step Process for Epstein-Barr Virus Latency Establishment and Consequences for B Cell Tumorigenesis. PLoS Pathog. 2015, 11, e1004656. [CrossRef]

32. Yoshida, M.; Murata, T.; Ashio, K.; Narita, Y.; Watanabe, T.; Al Masud, H.M.A.; Sato, Y.; Goshima, F.; Kimura, H. Characterization of a Suppressive Cis-acting Element in the Epstein-Barr Virus LMP1 Promoter. Front. Microbiol. 2017, 8, 2302. [CrossRef]

33. Price, A.M.; Messinger, J.E.; Luftig, M.A. c-Myc Represses Transcription of Epstein-Barr Virus Latent Membrane Protein 1 Early after Primary B Cell Infection. J. Virol. 2018, 92, e01178-17. [CrossRef] [PubMed]

34. Wang, F.; Tsang, S.F.; Kurilla, M.G.; Cohen, J.I.; Kieff, E. Epstein-Barr virus nuclear antigen 2 transactivates latent membrane protein LMP1. J. Virol. 1990, 64, 3407-3416. [CrossRef] [PubMed]

35. Wang, L.; Grossman, S.R.; Kieff, E. Epstein-Barr virus nuclear protein 2 interacts with p300, CBP, and PCAF histone acetyltransferases in activation of the LMP1 promoter. Proc. Natl. Acad. Sci. USA 2000, 97, 430-435. [CrossRef]

36. Demetriades, C.; Mosialos, G. The LMP1 promoter can be transactivated directly by NF-kappaB. J. Virol. 2009, 83, 5269-5277. [CrossRef] [PubMed]

37. Johansson, P.; Jansson, A.; Ruetschi, U.; Rymo, L. Nuclear factor-kappaB binds to the Epstein-Barr Virus LMP1 promoter and upregulates its expression. J. Virol. 2009, 83, 1393-1401. [CrossRef]

38. Murata, T.; Noda, C.; Narita, Y.; Watanabe, T.; Yoshida, M.; Ashio, K.; Sato, Y.; Goshima, F.; Kanda, T.; Yoshiyama, H.; et al. Induction of Epstein-Barr Virus Oncoprotein LMP1 by Transcription Factors AP-2 and Early B Cell Factor. J. Virol. 2016, 90, 3873-3889. [CrossRef]

39. Ning, S.; Hahn, A.M.; Huye, L.E.; Pagano, J.S. Interferon Regulatory Factor 7 Regulates Expression of Epstein-Barr Virus Latent Membrane Protein 1: A Regulatory Circuit. J. Virol. 2003, 77, 9359-9368. [CrossRef] [PubMed]

40. Sjoblom, A.; Yang, W.; Palmqvist, L.; Jansson, A.; Rymo, L. An ATF/CRE element mediates both EBNA2-dependent and EBNA2-independent activation of the Epstein-Barr virus LMP1 gene promoter. J. Virol. 1998, 72, 1365-1376. [CrossRef]

41. Wang, L.W.; Jiang, S.; Gewurz, B.E. Epstein-Barr Virus LMP1-Mediated Oncogenicity. J. Virol. 2017, 91, e01718-16. [CrossRef] [PubMed]

42. Yanagi, Y.; Okuno, Y.; Narita, Y.; Al Masud, H.A.; Watanabe, T.; Sato, Y.; Kanda, T.; Kimura, H.; Murata, T. RNAseq analysis identifies involvement of EBNA2 in PD-L1 induction during Epstein-Barr virus infection of primary B cells. Virology 2021, 557, 44-54. [CrossRef]

43. Ling, P.D.; Hsieh, J.J.; Ruf, I.K.; Rawlins, D.R.; Hayward, S.D. EBNA-2 upregulation of Epstein-Barr virus latency promoters and the cellular CD23 promoter utilizes a common targeting intermediate, CBF1. J. Virol. 1994, 68, 5375-5383. [CrossRef]

44. Boccellato, F.; Anastasiadou, E.; Rosato, P.; Kempkes, B.; Frati, L.; Faggioni, A. EBNA2 interferes with the germinal center phenotype by downregulating BCL6 and TCL1 in non-Hodgkin's lymphoma cells. J. Virol. 2007, 81, 2274-2282. [CrossRef] [PubMed]

45. Kis, L.L.; Salamon, D.; Persson, E.K.; Nagy, N.; Scheeren, F.; Spits, H.; Klein, G.; Klein, E. IL-21 imposes a type II EBV gene expression on type III and type I B cells by the repression of C-and activation of LMP-1-promoter. Proc. Natl. Acad. Sci. USA 2009, 107, 872-877. [CrossRef] [PubMed]

46. Chen, H.; Hutt-Fletcher, L.; Cao, L.; Hayward, S.D. A Positive Autoregulatory Loop of LMP1 Expression and STAT Activation in Epithelial Cells Latently Infected with Epstein-Barr Virus. J. Virol. 2003, 77, 4139-4148. [CrossRef]

47. Kis, L.L.; Gerasimčik, N.; Salamon, D.; Persson, E.K.; Nagy, N.; Klein, G.; Severinson, E.; Klein, E. STAT6 signaling pathway activated by the cytokines IL-4 and IL-13 induces expression of the Epstein-Barr virus-encoded protein LMP-1 in absence of EBNA-2: Implications for the type II EBV latent gene expression in Hodgkin lymphoma. Blood 2011, 117, 165-174. [CrossRef]

48. Kis, L.L.; Takahara, M.; Nagy, N.; Klein, G.; Klein, E. Cytokine mediated induction of the major Epstein-Barr virus (EBV)-encoded transforming protein, LMP-1. Immunol. Lett. 2006, 104, 83-88. [CrossRef] [PubMed]

49. Kis, L.L.; Takahara, M.; Nagy, N.; Klein, G.; Klein, E. IL-10 can induce the expression of EBV-encoded latent membrane protein-1 (LMP-1) in the absence of EBNA-2 in B lymphocytes and in Burkitt lymphoma- and NK lymphoma-derived cell lines. Blood 2006, 107, 2928-2935. [CrossRef]

50. Chen, H.; Lee, J.M.; Zong, Y.; Borowitz, M.; Ng, M.H.; Ambinder, R.F.; Hayward, S.D. Linkage between STAT Regulation and Epstein-Barr Virus Gene Expression in Tumors. J. Virol. 2001, 75, 2929-2937. [CrossRef]

51. Noda, C.; Murata, T.; Kanda, T.; Yoshiyama, H.; Sugimoto, A.; Kawashima, D.; Saito, S.; Isomura, H.; Tsurumi, T. Identification and Characterization of CCAAT Enhancer-binding Protein (C/EBP) as a Transcriptional Activator for Epstein-Barr Virus Oncogene Latent Membrane Protein 1. J. Biol. Chem. 2011, 286, 42524-42533. [CrossRef]

52. Kenney, S.C.; Mertz, J.E. Regulation of the latent-lytic switch in Epstein-Barr virus. Semin. Cancer Biol. 2014, 26, 60-68. [CrossRef] [PubMed] 
53. McKenzie, J.; El-Guindy, A. Epstein-Barr Virus Lytic Cycle Reactivation. Curr. Top. Microbiol. Immunol. $2015,391,237-261$. [CrossRef] [PubMed]

54. Murata, T.; Tsurumi, T. Switching of EBV cycles between latent and lytic states. Rev. Med. Virol. 2014, 24, 142-153. [CrossRef] [PubMed]

55. Miller, G.; El-Guindy, A.; Countryman, J.; Ye, J.; Gradoville, L. Lytic Cycle Switches of Oncogenic Human Gammaherpesviruses Adv. Cancer Res. 2007, 97, 81-109. [CrossRef] [PubMed]

56. Sinclair, A.J. bZIP proteins of human gammaherpesviruses. J. Gen. Virol. 2003, 84, 1941-1949. [CrossRef]

57. Stolz, M.L.; McCormick, C. The bZIP Proteins of Oncogenic Viruses. Viruses 2020, 12, 757. [CrossRef]

58. Packham, G.; Economou, A.; Rooney, C.M.; Rowe, D.T.; Farrell, P.J. Structure and function of the Epstein-Barr virus BZLF1 protein. J. Virol. 1990, 64, 2110-2116. [CrossRef]

59. Lieberman, P.M.; Hardwick, J.M.; Sample, J.; Hayward, G.S.; Hayward, S.D. The zta transactivator involved in induction of lytic cycle gene expression in Epstein-Barr virus-infected lymphocytes binds to both AP-1 and ZRE sites in target promoter and enhancer regions. J. Virol. 1990, 64, 1143-1155. [CrossRef]

60. Urier, G.; Buisson, M.; Chambard, P.; Sergeant, A. The Epstein-Barr virus early protein EB1 activates transcription from different responsive elements including AP-1 binding sites. EMBO J. 1989, 8, 1447-1453. [CrossRef]

61. Bhende, P.M.; Seaman, W.T.; Delecluse, H.-J.; Kenney, S.C. The EBV lytic switch protein, Z, preferentially binds to and activates the methylated viral genome. Nat. Genet. 2004, 36, 1099-1104. [CrossRef]

62. Dickerson, S.J.; Xing, Y.; Robinson, A.R.; Seaman, W.T.; Gruffat, H.; Kenney, S.C. Methylation-Dependent Binding of the Epstein-Barr Virus BZLF1 Protein to Viral Promoters. PLoS Pathog. 2009, 5, e1000356. [CrossRef] [PubMed]

63. Woellmer, A.; Arteaga-Salas, J.M.; Hammerschmidt, W. BZLF1 governs CpG-methylated chromatin of Epstein-Barr Virus reversing epigenetic repression. PLoS Pathog. 2012, 8, e1002902. [CrossRef] [PubMed]

64. Tsurumi, T.; Fujita, M.; Kudoh, A. Latent and lytic Epstein-Barr virus replication strategies. Rev. Med Virol. 2005, 15, 3-15. [CrossRef] [PubMed]

65. Gruffat, H.; Duran, N.; Buisson, M.; Wild, F.; Buckland, R.; Sergeant, A. Characterization of an R-binding site mediating the R-induced activation of the Epstein-Barr virus BMLF1 promoter. J. Virol. 1992, 66, 46-52. [CrossRef] [PubMed]

66. Manet, E.; Rigolet, A.; Gruffat, H.; Giot, J.-F.; Sergeant, A. Domains of the Epstein-Barr virus (EBV) transcription factor R required for dimerization, DNA binding and activation. Nucleic Acids Res. 1991, 19, 2661-2667. [CrossRef]

67. Chang, L.-K.; Chung, J.-Y.; Hong, Y.-R.; Ichimura, T.; Nakao, M.; Liu, S.-T. Activation of Sp1-mediated transcription by Rta of Epstein-Barr virus via an interaction with MCAF1. Nucleic Acids Res. 2005, 33, 6528-6539. [CrossRef] [PubMed]

68. Robinson, A.R.; Kwek, S.S.; Hagemeier, S.R.; Wille, C.K.; Kenney, S.C. Cellular transcription factor Oct-1 interacts with the Epstein-Barr virus BRLF1 protein to promote disruption of viral latency. J. Virol. 2011, 85, 8940-8953. [CrossRef]

69. Darr, C.D.; Mauser, A.; Kenney, S. Epstein-Barr Virus Immediate-Early Protein BRLF1 Induces the Lytic Form of Viral Replication through a Mechanism Involving Phosphatidylinositol-3 Kinase Activation. J. Virol. 2001, 75, 6135-6142. [CrossRef]

70. Lee, Y.-H.; Chiu, Y.-F.; Wang, W.-H.; Chang, L.-K.; Liu, S.-T. Activation of the ERK signal transduction pathway by Epstein-Barr virus immediate-early protein Rta. J. Gen. Virol. 2008, 89, 2437-2446. [CrossRef]

71. Flemington, E.; Speck, S.H. Identification of phorbol ester response elements in the promoter of Epstein-Barr virus putative lytic switch gene BZLF1. J. Virol. 1990, 64, 1217-1226. [CrossRef]

72. Daibata, M.; Speck, S.H.; Mulder, C.; Sairenji, T. Regulation of the BZLF1 Promoter of Epstein-Barr Virus by Second Messengers in Anti-immunoglobulin-Treated B Cells. Virology 1994, 198, 446-454. [CrossRef]

73. Liu, S.; Borras, A.M.; Liu, P.; Suske, G.; Speck, S.H. Binding of the Ubiquitous Cellular Transcription Factors Sp1 and Sp3 to the ZI Domains in the Epstein-Barr Virus Lytic Switch BZLF1 Gene Promoter. Virology 1997, 228, 11-18. [CrossRef]

74. Liu, S.; Liu, P.; Borras, A.; Chatila, T.; Speck, S.H. Cyclosporin A-sensitive induction of the Epstein-Barr virus lytic switch is mediated via a novel pathway involving a MEF2 family member. EMBO J. 1997, 16, 143-153. [CrossRef]

75. Murata, T.; Narita, Y.; Sugimoto, A.; Kawashima, D.; Kanda, T.; Tsurumi, T.; Li, M.-T.; Di, W.; Xu, H.; Yang, Y.-K.; et al. Contribution of Myocyte Enhancer Factor 2 Family Transcription Factors to BZLF1 Expression in Epstein-Barr Virus Reactivation from Latency. J. Virol. 2013, 87, 10148-10162. [CrossRef]

76. Nawandar, D.M.; Wang, A.; Makielski, K.; Lee, D.; Ma, S.; Barlow, E.; Reusch, J.; Jiang, R.; Wille, C.K.; Greenspan, D.; et al. Differentiation-Dependent KLF4 Expression Promotes Lytic Epstein-Barr Virus Infection in Epithelial Cells. PLoS Pathog. 2015, 11, e1005195. [CrossRef]

77. Sun, C.C.; Thorley-Lawson, D.A. Plasma cell-specific transcription factor XBP-1s binds to and transactivates the Epstein-Barr virus BZLF1 promoter. J. Virol. 2007, 81, 13566-13577. [CrossRef]

78. Wang, Y.-C.J.; Huang, J.-M.; Montalvo, E.A. Characterization of Proteins Binding to the ZII Element in the Epstein-Barr Virus BZLF1 Promoter: Transactivation by ATF1. Virology 1997, 227, 323-330. [CrossRef]

79. Flemington, E.; Speck, S.H. Autoregulation of Epstein-Barr virus putative lytic switch gene BZLF1. J. Virol. 1990, 64, 1227-1232. [CrossRef] [PubMed]

80. Kraus, R.J.; Cordes, B.-L.A.; Sathiamoorthi, S.; Patel, P.; Yuan, X.; Iempridee, T.; Yu, X.; Lee, D.L.; Lambert, P.F.; Mertz, J.E. Reactivation of Epstein-Barr Virus by HIF-1 $\alpha$ Requires p53. J. Virol. 2020, 94, e00722-20. [CrossRef] 
81. Iempridee, T.; Das, S.; Xu, I.; Mertz, J.E. Transforming growth factor beta-induced reactivation of Epstein-Barr virus involves multiple Smad-binding elements cooperatively activating expression of the latent-lytic switch BZLF1 gene. J. Virol. 2011, 85, 7836-7848. [CrossRef] [PubMed]

82. Kraus, R.J.; Perrigoue, J.G.; Mertz, J.E. ZEB Negatively Regulates the Lytic-Switch BZLF1 Gene Promoter of Epstein-Barr Virus. J. Virol. 2003, 77, 199-207. [CrossRef]

83. Yu, X.; Wang, Z.; Mertz, J.E. ZEB1 Regulates the Latent-Lytic Switch in Infection by Epstein-Barr Virus. PLoS Pathog. 2007, 3, e194. [CrossRef]

84. Liu, P.; Liu, S.; Speck, S.H. Identification of a negative cis element within the ZII domain of the Epstein-Barr virus lytic switch BZLF1 gene promoter. J. Virol. 1998, 72, 8230-8239. [CrossRef]

85. Yu, X.; McCarthy, P.J.; Lim, H.-J.; Iempridee, T.; Kraus, R.J.; Gorlen, D.A.; Mertz, J.E. The ZIIR Element of the Epstein-Barr Virus BZLF1 Promoter Plays a Central Role in Establishment and Maintenance of Viral Latency. J. Virol. 2011, 85, 5081-5090. [CrossRef]

86. Guo, R.; Jiang, C.; Zhang, Y.; Govande, A.; Trudeau, S.J.; Chen, F.; Fry, C.J.; Puri, R.; Wolinsky, E.; Schineller, M.; et al. MYC Controls the Epstein-Barr Virus Lytic Switch. Mol. Cell 2020, 78, 653-669. [CrossRef]

87. Lv, D.-W.; Zhang, K.; Li, R. Interferon regulatory factor 8 regulates caspase-1 expression to facilitate Epstein-Barr virus reactivation in response to B cell receptor stimulation and chemical induction. PLoS Pathog. 2018, 14, e1006868. [CrossRef]

88. Glaser, G.; Vogel, M.; Wolf, H.; Niller, H.H. Regulation of the Epstein-Barr viral immediate early BRLF1 promoter through a distal NF1 site. Arch. Virol. 1998, 143, 1967-1983. [CrossRef]

89. Reusch, J.A.; Nawandar, D.M.; Wright, K.L.; Kenney, S.C.; Mertz, J.E. Cellular Differentiation Regulator BLIMP1 Induces EpsteinBarr Virus Lytic Reactivation in Epithelial and B Cells by Activating Transcription from both the R and Z Promoters. J. Virol. 2015, 89, 1731-1743. [CrossRef]

90. Sarkar, R.; Verma, S.C. Egr-1 regulates RTA transcription through a cooperative involvement of transcriptional regulators. Oncotarget 2017, 8, 91425-91444. [CrossRef]

91. Zalani, S.; Coppage, A.; Holley-Guthrie, E.; Kenney, S. The cellular YY1 transcription factor binds a cis-acting, negatively regulating element in the Epstein-Barr virus BRLF1 promoter. J. Virol. 1997, 71, 3268-3274. [CrossRef]

92. Zalani, S.; Holley-Guthrie, E.A.; Gutsch, D.E.; Kenney, S.C. The Epstein-Barr virus immediate-early promoter BRLF1 can be activated by the cellular Sp1 transcription factor. J. Virol. 1992, 66, 7282-7292. [CrossRef] [PubMed]

93. Han, Z.; Marendy, E.; Wang, Y.D.; Yuan, J.; Sample, J.T.; Swaminathan, S. Multiple roles of Epstein-Barr virus SM protein in lytic replication. J. Virol. 2007, 81, 4058-4069. [CrossRef] [PubMed]

94. Juillard, F.; Bazot, Q.; Mure, F.; Tafforeau, L.; Macri, C.; Rabourdin-Combe, C.; Lotteau, V.; Manet, E.; Gruffat, H. Epstein-Barr virus protein EB2 stimulates cytoplasmic mRNA accumulation by counteracting the deleterious effects of SRp20 on viral mRNAs. Nucleic Acids Res. 2012, 40, 6834-6849. [CrossRef]

95. Key, S.C.; Yoshizaki, T.; Pagano, J.S. The Epstein-Barr virus (EBV) SM protein enhances pre-mRNA processing of the EBV DNA polymerase transcript. J. Virol. 1998, 72, 8485-8492. [CrossRef]

96. Nicewonger, J.; Suck, G.; Bloch, D.; Swaminathan, S. Epstein-Barr Virus (EBV) SM Protein Induces and Recruits Cellular Sp110b To Stabilize mRNAs and Enhance EBV Lytic Gene Expression. J. Virol. 2004, 78, 9412-9422. [CrossRef] [PubMed]

97. Ruvolo, V.; Gupta, A.K.; Swaminathan, S. Epstein-Barr Virus SM Protein Interacts with mRNA In Vivo and Mediates a GeneSpecific Increase in Cytoplasmic mRNA. J. Virol. 2001, 75, 6033-6041. [CrossRef]

98. Verma, D.; Bais, S.; Gaillard, M.; Swaminathan, S. Epstein-Barr Virus SM Protein Utilizes Cellular Splicing Factor SRp20 To Mediate Alternative Splicing. J. Virol. 2010, 84, 11781-11789. [CrossRef] [PubMed]

99. Verma, D.; Church, T.M.; Swaminathan, S. Epstein-Barr virus co-opts TFIIH component XPB to specifically activate essential viral lytic promoters. Proc. Natl. Acad. Sci. USA 2020, 117, 13044-13055. [CrossRef] [PubMed]

100. Verma, D.; Swaminathan, S. Epstein-Barr Virus SM Protein Functions as an Alternative Splicing Factor. J. Virol. 2008, 82, 7180-7188. [CrossRef]

101. Fixman, E.D.; Hayward, G.S.; Hayward, S.D. Replication of Epstein-Barr virus oriLyt: Lack of a dedicated virally encoded origin-binding protein and dependence on Zta in cotransfection assays. J. Virol. 1995, 69, 2998-3006. [CrossRef]

102. Su, M.-T.; Liu, I.-H.; Wu, C.-W.; Chang, S.-M.; Tsai, C.-H.; Yang, P.-W.; Chuang, Y.-C.; Lee, C.-P.; Chen, M.-R. Uracil DNA Glycosylase BKRF3 Contributes to Epstein-Barr Virus DNA Replication through Physical Interactions with Proteins in Viral DNA Replication Complex. J. Virol. 2014, 88, 8883-8899. [CrossRef] [PubMed]

103. Schepers, A.; Pich, D.; Hammerschmidt, W. Activation of oriLyt, the lytic origin of DNA replication of Epstein-Barr virus, by BZLF1. Virology 1996, 220, 367-376. [CrossRef]

104. Chakravorty, A.; Sugden, B.; Johannsen, E.C. An Epigenetic Journey: Epstein-Barr Virus Transcribes Chromatinized and Subsequently Unchromatinized Templates during Its Lytic Cycle. J. Virol. 2019, 93, e02247-18. [CrossRef] [PubMed]

105. Aubry, V.; Mure, F.; Mariamé, B.; Deschamps, T.; Wyrwicz, L.; Manet, E.; Gruffat, H. Epstein-Barr Virus Late Gene Transcription Depends on the Assembly of a Virus-Specific Preinitiation Complex. J. Virol. 2014, 88, 12825-12838. [CrossRef]

106. Gruffat, H.; Kadjouf, F.; Mariamé, B.; Manet, E. The Epstein-Barr Virus BcRF1 Gene Product Is a TBP-Like Protein with an Essential Role in Late Gene Expression. J. Virol. 2012, 86, 6023-6032. [CrossRef]

107. Gruffat, H.; Marchione, R.; Manet, E. Herpesvirus Late Gene Expression: A Viral-Specific Pre-initiation Complex Is Key. Front. Microbiol. 2016, 7, 869. [CrossRef] 
108. Watanabe, T.; Narita, Y.; Yoshida, M.; Sato, Y.; Goshima, F.; Kimura, H.; Murata, T. The Epstein-Barr Virus BDLF4 Gene Is Required for Efficient Expression of Viral Late Lytic Genes. J. Virol. 2015, 89, 10120-10124. [CrossRef] [PubMed]

109. Li, J.; Walsh, A.; Lam, T.T.; Delecluse, H.-J.; El-Guindy, A. A single phosphoacceptor residue in BGLF3 is essential for transcription of Epstein-Barr virus late genes. PLoS Pathog. 2019, 15, e1007980. [CrossRef]

110. Sato, Y.; Watanabe, T.; Suzuki, C.; Abe, Y.; Al Masud, H.M.A.; Inagaki, T.; Yoshida, M.; Suzuki, T.; Goshima, F.; Adachi, J.; et al. S-Like-Phase Cyclin-Dependent Kinases Stabilize the Epstein-Barr Virus BDLF4 Protein to Temporally Control Late Gene Transcription. J. Virol. 2019, 93, e01707-18. [CrossRef] [PubMed]

111. Murata, T. Regulation of Epstein-Barr virus reactivation from latency. Microbiol. Immunol. 2014, 58, 307-317. [CrossRef] [PubMed]

112. Lee, C.-P.; Chen, M.-R. Conquering the Nuclear Envelope Barriers by EBV Lytic Replication. Viruses 2021, 13, 702. [CrossRef]

113. Murata, T. Encyclopedia of EBV-Encoded Lytic Genes: An Update. Adv. Exp. Med. Biol. 2018, 1045, 395-412. [CrossRef] [PubMed]

114. Fernandez, A.F.; Rosales, C.; Nieva, P.L.; Graña, O.; Ballestar, E.; Ropero, S.; Espada, J.; Melo, S.; Lujambio, A.; Fraga, M.; et al. The dynamic DNA methylomes of double-stranded DNA viruses associated with human cancer. Genome Res. 2009, 19, 438-451. [CrossRef] [PubMed]

115. Johannsen, E.; Luftig, M.; Chase, M.R.; Weicksel, S.; Cahir-McFarland, E.; Illanes, D.; Sarracino, D.; Kieff, E. Proteins of purified Epstein-Barr virus. Proc. Natl. Acad. Sci. USA 2004, 101, 16286-16291. [CrossRef]

116. Kalla, M.; Schmeinck, A.; Bergbauer, M.; Pich, D.; Hammerschmidt, W. AP-1 homolog BZLF1 of Epstein-Barr virus has two essential functions dependent on the epigenetic state of the viral genome. Proc. Natl. Acad. Sci. USA 2009, 107, 850-855. [CrossRef]

117. Ichikawa, T.; Okuno, Y.; Sato, Y.; Goshima, F.; Yoshiyama, H.; Kanda, T.; Kimura, H.; Murata, T. Regulation of Epstein-Barr Virus Life Cycle and Cell Proliferation by Histone H3K27 Methyltransferase EZH2 in Akata Cells. mSphere 2018, 3, e00478-18. [CrossRef]

118. Tsai, K.; Chan, L.; Gibeault, R.; Conn, K.; Dheekollu, J.; Domsic, J.; Marmorstein, R.; Schang, L.; Lieberman, P.M. Viral Reprogramming of the Daxx Histone H3.3 Chaperone during Early Epstein-Barr Virus Infection. J. Virol. 2014, 88, 14350-14363. [CrossRef]

119. Alinari, L.; Mahasenan, K.V.; Yan, F.; Karkhanis, V.; Chung, J.-H.; Smith, E.M.; Quinion, C.; Smith, P.L.; Kim, L.; Patton, J.T.; et al. Selective inhibition of protein arginine methyltransferase 5 blocks initiation and maintenance of B-cell transformation. Blood 2015, 125, 2530-2543. [CrossRef]

120. Leonard, S.; Gordon, N.; Smith, N.; Rowe, M.; Murray, P.G.; Woodman, C.B. Arginine Methyltransferases Are Regulated by Epstein-Barr Virus in B Cells and Are Differentially Expressed in Hodgkin's Lymphoma. Pathogens 2012, 1, 52-64. [CrossRef]

121. Liu, C.-D.; Cheng, C.-P.; Fang, J.-S.; Chen, L.-C.; Zhao, B.; Kieff, E.; Peng, C.-W. Modulation of Epstein-Barr Virus Nuclear Antigen 2-dependent transcription by protein arginine methyltransferase 5. Biochem. Biophys. Res. Commun. 2013, 430, 1097-1102. [CrossRef]

122. Shire, K.; Kapoor, P.; Jiang, K.; Hing, M.N.T.; Sivachandran, N.; Nguyen, T.; Frappier, L. Regulation of the EBNA1 Epstein-Barr Virus Protein by Serine Phosphorylation and Arginine Methylation. J. Virol. 2006, 80, 5261-5272. [CrossRef]

123. Hansen, K.D.; Sabunciyan, S.; Langmead, B.; Nagy, N.; Curley, R.; Klein, G.; Klein, E.; Salamon, D.; Feinberg, A.P. Large-scale hypomethylated blocks associated with Epstein-Barr virus-induced B-cell immortalization. Genome Res. 2014, 24, 177-184. [CrossRef]

124. Hernando, H.; Islam, A.B.; Rodriguez-Ubreva, J.; Forné, I.; Ciudad, L.; Imhof, A.; Shannon-Lowe, C.; Ballestar, E. Epstein-Barr virus-mediated transformation of $\mathrm{B}$ cells induces global chromatin changes independent to the acquisition of proliferation. Nucleic Acids Res. 2014, 42, 249-263. [CrossRef]

125. Hernando, H.; Shannon-Lowe, C.; Islam, A.B.; Al-Shahrour, F.; Rodriguez-Ubreva, J.; Cortez, V.C.R.; Javierre, B.M.; Mangas, C.; Fernández, A.F.; Parra, M.; et al. The B cell transcription program mediates hypomethylation and overexpression of key genes in Epstein-Barr virus-associated proliferative conversion. Genome Biol. 2013, 14, R3. [CrossRef]

126. Stanland, L.J.; Luftig, M.A. The Role of EBV-Induced Hypermethylation in Gastric Cancer Tumorigenesis. Viruses 2020, $12,1222$. [CrossRef]

127. Kaneda, A.; Matsusaka, K.; Aburatani, H.; Fukayama, M. Epstein-Barr virus infection as an epigenetic driver of tumorigenesis. Cancer Res. 2012, 72, 3445-3450. [CrossRef]

128. Pott, S.; Lieb, J.D. What are super-enhancers? Nat. Genet. 2015, 47, 8-12. [CrossRef]

129. Jiang, S.; Zhou, H.; Liang, J.; Gerdt, C.; Wang, C.; Ke, L.; Schmidt, S.C.; Narita, Y.; Ma, Y.; Wang, S.; et al. The Epstein-Barr Virus Regulome in Lymphoblastoid Cells. Cell Host Microbe 2017, 22, 561-573. [CrossRef]

130. Zhou, H.; Schmidt, S.C.; Jiang, S.; Willox, B.; Bernhardt, K.; Liang, J.; Johannsen, E.C.; Kharchenko, P.; Gewurz, B.E.; Kieff, E.; et al. Epstein-Barr Virus Oncoprotein Super-enhancers Control B Cell Growth. Cell Host Microbe 2015, 17, 205-216. [CrossRef]

131. Gunnell, A.; Webb, H.M.; Wood, C.D.; McClellan, M.J.; Wichaidit, B.; Kempkes, B.; Jenner, R.G.; Osborne, C.; Farrell, P.J.; West, M.J. RUNX super-enhancer control through the Notch pathway by Epstein-Barr virus transcription factors regulates B cell growth. Nucleic Acids Res. 2016, 44, 4636-4650. [CrossRef]

132. Hosoi, H.; Niibori-Nambu, A.; Nah, G.S.S.; Bahirvani, A.G.; Mok, M.M.H.; Sanda, T.; Kumar, A.P.; Tenen, D.G.; Ito, Y.; Sonoki, T.; et al. Super-enhancers for RUNX3 are required for cell proliferation in EBV-infected B cell lines. Gene 2021, 774, 145421. [CrossRef]

133. Frost, T.C.; Gewurz, B.E. Epigenetic crossroads of the Epstein-Barr virus B-cell relationship. Curr. Opin. Virol. 2018, 32, 15-23. [CrossRef] 
134. Hutchings, I.A.; Tierney, R.J.; Kelly, G.L.; Stylianou, J.; Rickinson, A.B.; Bell, A.I. Methylation Status of theEpstein-Barr Virus (EBV) BamHI W Latent Cycle Promoter and Promoter Activity: Analysis with Novel EBV-Positive Burkitt and LymphoblastoidCell Lines. J. Virol. 2006, 80, 10700-10711. [CrossRef]

135. Li, H.; Minarovits, J. Host Cell-Dependent Expression of Latent Epstein-Barr Virus Genomes: Regulation by DNA Methylation. Adv. Cancer Res. 2003, 89, 133-156. [CrossRef]

136. Park, J.-H.; Jeon, J.-P.; Shim, S.-M.; Nam, H.-Y.; Kim, J.-W.; Han, B.-G.; Lee, S. Wp specific methylation of highly proliferated LCLs. Biochem. Biophys. Res. Commun. 2007, 358, 513-520. [CrossRef]

137. Robertson, K.D.; Manns, A.; Swinnen, L.J.; Zong, J.C.; Gulley, M.L.; Ambinder, R.F. CpG methylation of the major Epstein-Barr virus latency promoter in Burkitt's lymphoma and Hodgkin's disease. Blood 1996, 88, 3129-3136. [CrossRef]

138. Schaefer, B.C.; Strominger, J.L.; Speck, S.H. Host-cell-determined methylation of specific Epstein-Barr virus promoters regulates the choice between distinct viral latency programs. Mol. Cell. Biol. 1997, 17, 364-377. [CrossRef]

139. Tao, Q.; Robertson, K.D.; Manns, A.; Hildesheim, A.; Ambinder, R.F. The Epstein-Barr virus major latent promoter Qp is constitutively active, hypomethylated, and methylation sensitive. J. Virol. 1998, 72, 7075-7083. [CrossRef]

140. Tierney, R.J.; Kirby, H.E.; Nagra, J.K.; Desmond, J.; Bell, A.I.; Rickinson, A.B. Methylation of Transcription Factor Binding Sites in the Epstein-Barr Virus Latent Cycle Promoter Wp Coincides with Promoter Down-Regulation during Virus-Induced B-Cell Transformation. J. Virol. 2000, 74, 10468-10479. [CrossRef]

141. Falk, K.I.; Szekely, L.; Aleman, A.; Ernberg, I. Specific methylation patterns in two control regions of Epstein-Barr virus latency: The LMP-1-coding upstream regulatory region and an origin of DNA replication (oriP). J. Virol. 1998, 72, 2969-2974. [CrossRef]

142. Li, J.; Liu, X.; Liu, M.; Che, K.; Luo, B. Methylation and expression of Epstein-Barr virus latent membrane protein 1, 2A and 2B in EBV-associated gastric carcinomas and cell lines. Dig. Liver Dis. 2016, 48, 673-680. [CrossRef]

143. Lu, F.; Wiedmer, A.; Martin, K.A.; Wickramasinghe, P.J.M.S.; Kossenkov, A.V.; Lieberman, P.M. Coordinate Regulation of TET2 and EBNA2 Controls the DNA Methylation State of Latent Epstein-Barr Virus. J. Virol. 2017, 91, e00804-17. [CrossRef]

144. Wille, C.K.; Li, Y.; Rui, L.; Johannsen, E.C.; Kenney, S.C. Restricted TET2 Expression in Germinal Center Type B Cells Promotes Stringent Epstein-Barr Virus Latency. J. Virol. 2017, 91, e01987-16. [CrossRef]

145. Guo, R.; Zhang, Y.; Teng, M.; Jiang, C.; Schineller, M.; Zhao, B.; Doench, J.G.; O’Reilly, R.J.; Cesarman, E.; Giulino-Roth, L.; et al. DNA methylation enzymes and PRC1 restrict B-cell Epstein-Barr virus oncoprotein expression. Nat. Microbiol. 2020, 5, 1051-1063. [CrossRef] [PubMed]

146. Herold, M.; Bartkuhn, M.; Renkawitz, R. CTCF: Insights into insulator function during development. Development 2012, 139, 1045-1057. [CrossRef] [PubMed]

147. Hnisz, D.; Day, D.S.; Young, R.A. Insulated Neighborhoods: Structural and Functional Units of Mammalian Gene Control. Cell 2016, 167, 1188-1200. [CrossRef]

148. Tempera, I.; Wiedmer, A.; Dheekollu, J.; Lieberman, P.M. CTCF Prevents the Epigenetic Drift of EBV Latency Promoter Qp. PLoS Pathog. 2010, 6, e1001048. [CrossRef]

149. Arvey, A.; Tempera, I.; Tsai, K.; Chen, H.-S.; Tikhmyanova, N.; Klichinsky, M.; Leslie, C.; Lieberman, P.M. An Atlas of the Epstein-Barr Virus Transcriptome and Epigenome Reveals Host-Virus Regulatory Interactions. Cell Host Microbe 2012, 12, $233-245$. [CrossRef] [PubMed]

150. Tempera, I.; Klichinsky, M.; Lieberman, P.M. EBV Latency Types Adopt Alternative Chromatin Conformations. PLoS Pathog. 2011, 7, e1002180. [CrossRef]

151. Tempera, I.; Lieberman, P.M. Epigenetic regulation of EBV persistence and oncogenesis. Semin. Cancer Biol. 2014, 26, 22-29. [CrossRef]

152. Arvey, A.; Tempera, I.; Lieberman, P.M. Interpreting the Epstein-Barr Virus (EBV) Epigenome Using High-Throughput Data. Viruses 2013, 5, 1042-1054. [CrossRef]

153. Day, L.; Chau, C.M.; Nebozhyn, M.; Rennekamp, A.J.; Showe, M.; Lieberman, P.M. Chromatin Profiling of Epstein-Barr Virus Latency Control Region. J. Virol. 2007, 81, 6389-6401. [CrossRef] [PubMed]

154. Imai, K.; Kamio, N.; Cueno, M.E.; Saito, Y.; Inoue, H.; Saito, I.; Ochiai, K. Role of the histone H3 lysine 9 methyltransferase Suv39 $\mathrm{h} 1$ in maintaining Epsteinn-Barr virus latency in B95-8 cells. FEBS J. 2014, 281, 2148-2158. [CrossRef]

155. Murata, T.; Kondo, Y.; Sugimoto, A.; Kawashima, D.; Saito, S.; Isomura, H.; Kanda, T.; Tsurumi, T. Epigenetic Histone Modification of Epstein-Barr Virus BZLF1 Promoter during Latency and Reactivation in Raji Cells. J. Virol. 2012, 86, 4752-4761. [CrossRef]

156. Ramasubramanyan, S.; Osborn, K.; Flower, K.; Sinclair, A.J. Dynamic Chromatin Environment of Key Lytic Cycle Regulatory Regions of the Epstein-Barr Virus Genome. J. Virol. 2012, 86, 1809-1819. [CrossRef] [PubMed]

157. Wu, X.; Zhang, Y. TET-mediated active DNA demethylation: Mechanism, function and beyond. Nat. Rev. Genet. 2017, 18, 517-534. [CrossRef]

158. Li, F.; Wan, M.; Zhang, B.; Peng, Y.; Zhou, Y.; Pi, C.; Xu, X.; Ye, L.; Zhou, X.; Zheng, L. Bivalent Histone Modifications and Development. Curr. Stem Cell Res. Ther. 2018, 13, 83-90. [CrossRef]

159. Djavadian, R.; Chiu, Y.-F.; Johannsen, E. An Epstein-Barr Virus-Encoded Protein Complex Requires an Origin of Lytic Replication In Cis to Mediate Late Gene Transcription. PLoS Pathog. 2016, 12, e1005718. [CrossRef]

160. Li, H.; Liu, S.; Hu, J.; Luo, X.; Li, N.; Bode, A.M.; Cao, Y. Epstein-Barr virus lytic reactivation regulation and its pathogenic role in carcinogenesis. Int. J. Biol. Sci. 2016, 12, 1309-1318. [CrossRef] 
161. Münz, C. Latency and lytic replication in Epstein-Barr virus-associated oncogenesis. Nat. Rev. Microbiol. 2019, 17, 691-700. [CrossRef]

162. Munz, C. The Role of Lytic Infection for Lymphomagenesis of Human gamma-Herpesviruses. Front. Cell. Infect. Microbiol. 2021, 11, 605258. [CrossRef]

163. Murata, T.; Okuno, Y.; Sato, Y.; Watanabe, T.; Kimura, H. Oncogenesis of CAEBV revealed: Intragenic deletions in the viral genome and leaky expression of lytic genes. Rev. Med. Virol. 2020, 30, e2095. [CrossRef]

164. Wu, C.-C.; Fang, C.-Y.; Huang, S.-Y.; Chiu, S.-H.; Lee, C.-H.; Chen, J.-Y. Perspective: Contribution of Epstein-Barr virus (EBV) Reactivation to the Carcinogenicity of Nasopharyngeal Cancer Cells. Cancers 2018, 10, 120. [CrossRef]

165. Katsumura, K.R.; Maruo, S.; Takada, K. EBV lytic infection enhances transformation of B-lymphocytes infected with EBV in the presence of T-lymphocytes. J. Med. Virol. 2012, 84, 504-510. [CrossRef]

166. Kimura, H.; Okuno, Y.; Sato, Y.; Watanabe, T.; Murata, T. Deletion of Viral microRNAs in the Oncogenesis of Epstein-Barr Virus-Associated Lymphoma. Front. Microbiol. 2021, 12, 667968. [CrossRef]

167. Okuno, Y.; Murata, T.; Sato, Y.; Muramatsu, H.; Ito, Y.; Watanabe, T.; Okuno, T.; Murakami, N.; Yoshida, K.; Sawada, A.; et al. Defective Epstein-Barr virus in chronic active infection and haematological malignancy. Nat. Microbiol. 2019, 4, 404-413. [CrossRef] [PubMed]

168. Ma, S.-D.; Hegde, S.; Young, K.H.; Sullivan, R.; Rajesh, D.; Zhou, Y.; Jankowska-Gan, E.; Burlingham, W.J.; Sun, X.; Gulley, M.L.; et al. A New Model of Epstein-Barr Virus Infection Reveals an Important Role for Early Lytic Viral Protein Expression in the Development of Lymphomas. J. Virol. 2011, 85, 165-177. [CrossRef] [PubMed]

169. Ma, S.-D.; Yu, X.; Mertz, J.E.; Gumperz, J.E.; Reinheim, E.; Zhou, Y.; Tang, W.; Burlingham, W.J.; Gulley, M.L.; Kenney, S.C. An Epstein-Barr Virus (EBV) Mutant with Enhanced BZLF1 Expression Causes Lymphomas with Abortive Lytic EBV Infection in a Humanized Mouse Model. J. Virol. 2012, 86, 7976-7987. [CrossRef] [PubMed]

170. Martini, M.; Capello, D.; Serraino, D.; Navarra, A.; Pierconti, F.; Cenci, T.; Gaidano, G.; Larocca, L.M. Characterization of variants in the promoter of EBV gene BZLF1 in normal donors, HIV-positive patients and in AIDS-related lymphomas. J. Infect. 2007, 54, 298-306. [CrossRef] [PubMed]

171. Tong, J.H.M.; Lo, K.W.; Au, F.W.L.; Huang, D.P.; To, K.-F. Re: Discrete Alterations in the BZLF1 Promoter in Tumor and Non-Tumor-Associated Epstein-Barr Virus. J. Natl. Cancer Inst. 2003, 95, 1008-1009. [CrossRef]

172. Bristol, J.A.; Djavadian, R.; Albright, E.R.; Coleman, C.B.; Ohashi, M.; Hayes, M.; Romero-Masters, J.C.; Barlow, E.A.; Farrell, P.J.; Rochford, R.; et al. A cancer-associated Epstein-Barr virus BZLF1 promoter variant enhances lytic infection. PLoS Pathog. 2018, 14, e1007179. [CrossRef]

173. Palser, A.L.; Grayson, N.E.; White, R.E.; Corton, C.; Correia, S.; Ba Abdullah, M.M.; Watson, S.J.; Cotten, M.; Arrand, J.R.; Murray, P.G.; et al. Genome Diversity of Epstein-Barr Virus from Multiple Tumor Types and Normal Infection. J. Virol. 2015, 89, $5222-5237$. [CrossRef]

174. Venturini, C.; Houldcroft, C.J.; Lazareva, A.; Wegner, F.; Morfopoulou, S.; Amrolia, P.J.; Golwala, Z.; Rao, A.; Marks, S.D.; Simmonds, J.; et al. Epstein-Barr virus (EBV) deletions as biomarkers of response to treatment of chronic active EBV. Br. J. Haematol. 2021, 195, 249-255. [CrossRef]

175. Lin, X.; Tsai, M.-H.; Shumilov, A.; Poirey, R.; Bannert, H.; Middeldorp, J.; Feederle, R.; Delecluse, H.-J. The Epstein-Barr Virus BART miRNA Cluster of the M81 Strain Modulates Multiple Functions in Primary B Cells. PLoS Pathog. 2015, 11, e1005344. [CrossRef] [PubMed]

176. Stuart, A.D.; Stewart, J.P.; Arrand, J.R.; Mackett, M. The Epstein-Barr virus encoded cytokine viral interleukin-10 enhances transformation of human B lymphocytes. Oncogene 1995, 11, 1711-1720. [PubMed]

177. Murata, T.; Iwata, S.; Alam Siddiquey, M.N.; Kanazawa, T.; Goshima, F.; Kawashima, D.; Kimura, H.; Tsurumi, T. Heat Shock Protein 90 Inhibitors Repress Latent Membrane Protein 1 (LMP1) Expression and Proliferation of Epstein-Barr Virus-Positive Natural Killer Cell Lymphoma. PLoS ONE 2013, 8, e63566. [CrossRef]

178. Suzuki, M.; Takeda, T.; Nakagawa, H.; Iwata, S.; Watanabe, T.; Siddiquey, M.N.; Goshima, F.; Murata, T.; Kawada, J.I.; Ito, Y.; et al. The heat shock protein 90 inhibitor BIIB021 suppresses the growth of T and natural killer cell lymphomas. Front. Microbiol. 2015, 6, 280. [CrossRef] [PubMed]

179. Iwata, S.; Saito, T.; Ito, Y.; Kamakura, M.; Gotoh, K.; Kawada, J.-I.; Nishiyama, Y.; Kimura, H. Antitumor activities of valproic acid on Epstein-Barr virus-associated T and natural killer lymphoma cells. Cancer Sci. 2012, 103, 375-381. [CrossRef]

180. Siddiquey, M.N.; Nakagawa, H.; Iwata, S.; Kanazawa, T.; Suzuki, M.; Imadome, K.; Fujiwara, S.; Goshima, F.; Murata, T.; Kimura, H. Anti-tumor effects of suberoylanilide hydroxamic acid on Epstein-Barr virus-associated T cell and natural killer cell lymphoma. Cancer Sci. 2014, 105, 713-722. [CrossRef]

181. Nishikawa, J.; Iizasa, H.; Yoshiyama, H.; Nakamura, M.; Saito, M.; Sasaki, S.; Shimokuri, K.; Yanagihara, M.; Sakai, K.; Suehiro, Y.; et al. The Role of Epigenetic Regulation in Epstein-Barr Virus-Associated Gastric Cancer. Int. J. Mol. Sci. 2017, 18, 1606. [CrossRef]

182. Chan, A.T.; Tao, Q.; Robertson, K.D.; Flinn, I.W.; Mann, R.B.; Klencke, B.; Kwan, W.H.; Leung, T.W.-T.; Johnson, P.J.; Ambinder, R.F. Azacitidine Induces Demethylation of the Epstein-Barr Virus Genome in Tumors. J. Clin. Oncol. 2004, 22, 1373-1381. [CrossRef] [PubMed]

183. Dalton, T.; Doubrovina, E.; Pankov, D.; Reynolds, I.R.C.; Scholze, H.; Selvakumar, A.; Vizconde, T.; Savalia, B.; Dyomin, V.; Weigel, C.; et al. Epigenetic reprogramming sensitizes immunologically silent EBV+ lymphomas to virus-directed immunotherapy. Blood 2020, 135, 1870-1881. [CrossRef] [PubMed] 
184. Yiu, S.P.T.; Dorothea, M.; Hui, K.F.; Chiang, A.K.S. Lytic Induction Therapy against Epstein-Barr Virus-Associated Malignancies: Past, Present, and Future. Cancers 2020, 12, 2142. [CrossRef]

185. Ghosh, S.K.; Perrine, S.P.; Williams, R.M.; Faller, D.V. Histone deacetylase inhibitors are potent inducers of gene expression in latent EBV and sensitize lymphoma cells to nucleoside antiviral agents. Blood 2012, 119, 1008-1017. [CrossRef] [PubMed] 